\title{
Old Yellow Enzyme-Catalysed Asymmetric Hydrogenation: Linking Family Roots with Improved Catalysis
}

\author{
Anika Scholtissek ${ }^{1}$, Dirk Tischler ${ }^{1}$, Adrie H. Westphal ${ }^{2}$, Willem J. H. van Berkel ${ }^{2}$ and \\ Caroline E. Paul ${ }^{3, *}$ \\ 1 Interdisciplinary Ecological Center, Institute of Biosciences, Environmental Microbiology Group, \\ Technical University Bergakademie Freiberg, 09599 Freiberg, Germany; anika.scholtissek@gmail.com (A.S.); \\ dirk-tischler@email.de (D.T.) \\ 2 Laboratory of Biochemistry, Wageningen University \& Research, Stippeneng 4, 6708 WE Wageningen, \\ The Netherlands; adrie.westphal@wur.nl (A.H.W.); willem.vanberkel@wur.nl (W.J.H.v.B.) \\ 3 Department of Biotechnology, Delft University of Technology, Van der Maasweg 9, \\ 2629 Delft, The Netherlands \\ * Correspondence: c.e.paul@tudelft.nl; Tel.: +31-1527-84616
}

Academic Editors: Cesar Mateo and Jose M. Palomo

Received: 16 March 2017; Accepted: 25 April 2017; Published: 29 April 2017

\begin{abstract}
Asymmetric hydrogenation of activated alkenes catalysed by ene-reductases from the old yellow enzyme family (OYEs) leading to chiral products is of potential interest for industrial processes. OYEs' dependency on the pyridine nucleotide coenzyme can be circumvented through established artificial hydride donors such as nicotinamide coenzyme biomimetics (NCBs). Several OYEs were found to exhibit higher reduction rates with NCBs. In this review, we describe a new classification of OYEs into three main classes by phylogenetic and structural analysis of characterized OYEs. The family roots are linked with their use as chiral catalysts and their mode of action with NCBs. The link between bioinformatics (sequence analysis), biochemistry (structure-function analysis), and biocatalysis (conversion, enantioselectivity and kinetics) can enable an early classification of a putative ene-reductase and therefore the indication of the binding mode of various activated alkenes.
\end{abstract}

Keywords: old yellow enzymes; nicotinamide coenzyme biomimetics; cofactor analogues; classification of OYE; oxidoreductases; asymmetric hydrogenation; selective reduction; phylogenetics

\section{Introduction}

The 2001 Nobel prize in chemistry awarded to William S. Knowles and Ryōji Noyori internationally highlighted the importance of catalysed asymmetric hydrogenation reactions [1]. Particularly, the creation of one to two chiral centres through asymmetric hydrogenation of $\mathrm{C}=\mathrm{C}$ bonds is a highly valuable reaction in organic synthesis [2]. Common synthetic routes for cis-hydrogenation are accomplished via homogeneous chiral catalysts composed of precious metals such as rhodium (Rh), ruthenium (Ru) or iridium (Ir), and phosphine ligands such as chiral monoand di-phosphines, $C_{2}$-symmetric bisoxazoline ligands or $C_{2}$-symmetric $N$-heterocyclic carbenes, respectively [3]. In comparison, synthetic methods for asymmetric trans-hydrogenation to afford the stereo-complementary products are scarce [4].

A highly competitive tool for asymmetric trans-hydrogenation is the biocatalytic route using ene-reductases (ERs) of the old yellow enzyme family (OYEs, EC 1.6.99.1). The performance of these enzymes is of potential interest for industrial processes due to their high regio-, stereoand enantioselectivity, and an expanding substrate scope [5-9]. The substrate spectrum of OYEs includes activated alkenes with an electron withdrawing group (EWG) such as aldehyde, ketone, 
anhydride [8,10,11], nitro [9,12,13], (di)ester [8,14-17], (di)carboxylic acid [18-20], cyclic imide [21-23], nitrile [24], $\beta$-cyanoacrylate [25], $\beta$-nitroacrylate [26], and several other functional groups [27]. There are many examples of the high industrial potential of OYEs for the synthesis of valuable target products [28-31]. YqjM was found to produce enantiomerically pure $(R)$-profens and is applied in the synthesis of $(R)$-flurbiprofen methyl ester [32]. Flurbiprofen belongs to the non-steroidal anti-inflammatory drugs (NSAIDs) and is used at the appearance of dental pain or sore throat. A library of OYEs was used for the asymmetric reduction of $\beta$-cyanoacrylate esters to yield a precursor of pregabalin, an anticonvulsant for epilepsy or fibromyalgia [33]. A similar OYE library reduced $\alpha-, \beta$ - and $\gamma$-substituted $\alpha, \beta$-unsaturated butyrolactones [34], structural components of macrocyclic antibiotics [34,35]. A valuable overview for OYE-catalysed reactions from recent studies has been compiled by Toogood and co-workers, including an extensive substrate profile of isolated OYEs [36].

OYEs are flavin mononucleotide (FMN)-containing ERs and catalyse the selective asymmetric reduction of activated $\mathrm{C}=\mathrm{C}$ bonds at the expense of the pyridine nucleotide coenzyme $\mathrm{NAD}(\mathrm{P}) \mathrm{H}$, following a bi-bi ping-pong kinetic mechanism (Scheme 1). In the reductive half-reaction, FMN is reduced through hydride transfer from $\mathrm{NAD}(\mathrm{P}) \mathrm{H}(\mathrm{C} 4)$ [37]. In the oxidative half-reaction, a hydride is transferred from the N5-atom of the reduced flavin to the $C \beta$-atom of the activated alkene. A tyrosine residue provides a proton to the $C \alpha$-atom, thus completing the reduction of the $C=C$ bond $[9,37,38]$. This mechanism leads to an anti-addition (trans-fashion) hydrogenation and is supported by recent quantum mechanics/molecular mechanics calculations [39]. The reductive half-reaction was experimentally investigated in detail for OYE1 by Massey and co-workers [40]. Binding of NADPH to the oxidised enzyme-FMN complex led to the observation of a transient concentration-dependent Michaelis complex. After NADPH binding, generation of the reduced enzyme-NADP ${ }^{+}$complex was noticed as a long wavelength absorbance band. Formation of this charge-transfer complex indicated that the electron and subsequent hydride transfer requires $\pi-\pi$ stacking between the pyridinium ring of the nicotinamide cofactor and the isoalloxazine ring of the FMN [40,41].

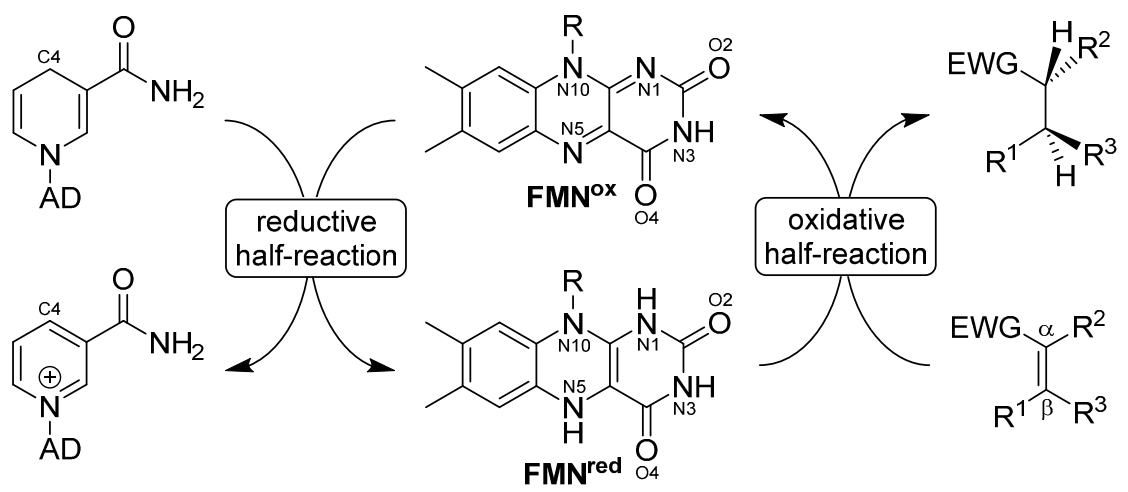

Scheme 1. OYE-catalysed asymmetric hydrogenation of activated alkenes through a bi-bi ping-pong mechanism producing one to two chiral centres. $\mathrm{AD}=$ adenine dinucleotide; $\mathrm{R}=$ ribose phosphate; EWG = electron withdrawing group.

Although NADPH is the preferred physiological coenzyme for OYE, the dependency on this commercially expensive compound can be circumvented by established recycling systems with dehydrogenases [12,18,42-45], with alternative sources of hydride [46,47], or through a nicotinamide-independent disproportionation coupling reaction [48-51]. A highly promising and elegant alternative is the use of relatively inexpensive nicotinamide coenzyme biomimetics (NCBs) [52-56]. The latter compounds retain the pyridine ring structure, substituted with varied functional groups either on the N1 nitrogen (NCBs 1-2, 6-7, Figure 1) or at the C3 carbon (NCBs 3-5) [55]. As with the natural coenzyme, the correct positioning of the pyridine ring in the active site is crucial for optimal hydride transfer $[52,57]$. 


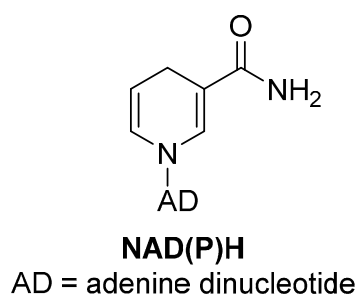

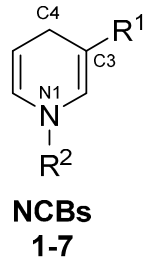

Figure 1. Nicotinamide coenzyme biomimetics (NCBs) previously used in OYE-catalysed hydrogenations to replace $\mathrm{NAD}(\mathrm{P}) \mathrm{H}[52,55,58]$.

Since 2013, several OYEs were found to exhibit high catalytic activities with different NCB analogues [52,57-59]. In a first study, YqjM, TsOYE and RmOYE were screened against NCBs 1-5 (Figure 1) [52], followed by more extensive kinetic studies with a panel of OYEs [59]. Depending on the applied NCBs, OYEs differ in their reaction rates and the catalytic efficiency $\left(k_{\mathrm{cat}} / K_{\mathrm{m}}\right)$ is at times even higher with NCBs than with the natural coenzyme, as discussed further in Section 4 [22,58,59].

In this review, we suggest linking the evolutionary history of OYEs with their activity with NCBs and their use as chiral catalysts on various substrates. To this end, we start with a phylogenetic classification of OYEs characterised thus far, and relate this classification to their structural and biocatalytic properties.

\section{Phylogenetic Classification of OYEs}

OYEs are ubiquitous in Nature [21,60]. Many ERs from the OYE family have been (recombinantly) expressed and characterised over the last 25 years. Currently, we have access to approximately 63 characterised and "ready-to-use" OYEs from plantae, fungi and bacteria. Tables 1 and 2 indicate the distribution of those well-characterised OYEs, with respect to their domain eukaryota (Table 1) and prokaryota (Table 2).

One third of the characterised OYEs have been obtained from eukaryota, mainly from the kingdom fungi, subkingdom of dikarya, phyla ascomyceta. However, the fungal OYEs originate from different families such as Saccharomycotina [61,62], and Pezizomycotina [63,64]. Fewer studies have been performed on OYEs originating from plants. Nevertheless, the enzymes AtOPR1-AtOPR3 from Arabidopsis thaliana [65,66], and LeOPR1-LeOPR3 from Solanum lycopersicum (tomato) $[67,68]$, were characterised according to their structure, function and physiological role. Two thirds of the characterised OYEs have been obtained from various classes of bacteria including proteobacteria (28\%) [69,70], actinobacteria (5\%) [22,71,72], bacteroidetes (5\%) [73,74], firmicutes (10\%) [75-77], deinococcus-thermus (3\%) [78-80], and cyanobacteria (17\%) [21,81].

The bacterial OYEs investigated until now have been categorised in classical and thermophilic-like (formerly YqjM-like) enzymes [9]. In 2016, Nizam and co-workers performed a comprehensive study of 424 putative OYEs from 60 fungal species and indicated a novel group among fungal OYEs [63]. However, none of these enzymes has been characterised thus far.

The first classical OYE (OYE1) was isolated from brewers' bottom yeast (Saccharomyces carlsbergensis) in $1932[5,82]$. The same protein was the basis for the first OYE crystal structure, uncovering a TIM-barrel topology, related to trimethylamine dehydrogenase [83]. Since then, many classical OYEs were identified from proteobacteria (NCR [84], MR [85], PETNR [8]), flavobacteria (Chr-OYE2 [74]), cyanobacteria [21], yeasts (OYE1-OYE3 [86,87], CYE [62]) and plants [67], outlined in Tables 1 and 2. 
Table 1. Sources of biochemically characterised eukaryotic OYEs.

\begin{tabular}{cccc}
\hline Kingdom & Enzyme (Accession Number) & Source & Reference(s) \\
\hline \multirow{6}{*}{ Fungi } & OYE1 (CAA37666) & Saccharomyces pastorianus & {$[61]$} \\
& OYE2 (AAA83386) & Sacharomyces cerevisiae & {$[87]$} \\
& OYE3 (AAA64522) & Saccharomyces cerevisiae & {$[88]$} \\
& EBP1 (AAA18013) & Candida albicans & {$[89]$} \\
& HYE1 (AAN09952) & Ogataea angusta & {$[90]$} \\
& HYE2 (AAN09953) & Ogataea angusta & {$[90]$} \\
& CYE (BAD24850) & Kluyveromyces marxianus & {$[62,91]$} \\
& KYE1 (AAA98815) & Kluyveromyces lactis & {$[6,92]$} \\
& OYE2.6 (ABN66026) & Scheffersomyces stipitis CBS 6054 & {$[93,94]$} \\
& ArOYE1-3 (AHL17019,AHL1720, AHL17021) & Ascochyta rabiei & {$[64]$} \\
& ClER (EEQ40235) & Clavispora lusitaniae ATCC 42720 & {$[95]$} \\
Plants & MgER (EDK41665) & Meyerozyma guilliermondii ATCC 6260 & {$[96]$} \\
\hline & LeOPR1 (NP_001234781) & Solanum lycopersicum & {$[68]$} \\
& LeOPR2 (NP_001233868) & Solanum lycopersicum & {$[67]$} \\
& LeOPR3 (NP_001233873) & Solanum lycopersicum & {$[67]$} \\
& AtOPR1 (NP_177794) & Arabidopsis thaliana & {$[65]$} \\
& AtOPR2 (NP_177795) & Arabidopsis thaliana & {$[97]$} \\
\hline
\end{tabular}

Colours are assigned based on a new classification according to the dendrogram in Figure 2. Yellow (class I) contains

classical OYEs originating from plants. Grey (class II) contains OYE homologues originating from fungal species.

Table 2. Sources of biochemically characterized prokaryotic OYEs.

\begin{tabular}{|c|c|c|c|}
\hline Group/Order & Enzyme (Ncbi Accession) & Source & Reference(s) \\
\hline \multirow{3}{*}{$\begin{array}{l}\text { Proteobacteria/ } \\
\alpha \text {-Proteobacteria }\end{array}$} & NerA/GTNR (CAA74280) & Agrobacterium radiobacter & [98] \\
\hline & NCR (AAV90509) & Zymomonas mobilis & [84] \\
\hline & GluER (AAW60280) & Gluconobacter oxidans DSM 2343 & [99] \\
\hline \multirow{4}{*}{$\begin{array}{l}\text { Proteobacteria/ } \\
\beta \text {-Proteobacteria }\end{array}$} & FOYE-1 (KRH78075) & Ferrovum sp. JA12 & [23] \\
\hline & RmER (ABF11721) & Cupriavidus metallidurans $\mathrm{CH} 34$ & [80] \\
\hline & Achr-OYE3 (AFK73187) & Achromobacter sp. JA81 & {$[16]$} \\
\hline & Achr-OYE4 (AFK73188) & Achromobacter sp. JA81 & {$[16,17]$} \\
\hline \multirow{12}{*}{$\begin{array}{l}\text { Proteobacteria/ } \\
\gamma \text {-Proteobacteria }\end{array}$} & MR (AAC43569) & Pseudomonas putida M10 & [85] \\
\hline & PETNR (AAB38683) & Enterobacter cloacae PB2 & [69] \\
\hline & NemR/NemA (BAA13186) & Escherichia coli & [100] \\
\hline & NemA2 (AHC69715) & Pseudomonas putida ATCC 17453 & [101] \\
\hline & XenA (AAF02538) & Pseudomonas putida II-B & [102] \\
\hline & XenA2 (AHH54488) & Pseudomonas putida ATCC 17453 & {$[101]$} \\
\hline & XenB (AAF02539) & Pseudomonas fluorescens I-C & {$[102]$} \\
\hline & XenB2 (AGS77941) & Pseudomonas putida ATCC 17453 & [101] \\
\hline & YersER (WP_032896199) & Yersinia bercovieri & [6] \\
\hline & SYE1 (AAN55488) & Shewanella oneidensis & [103] \\
\hline & SYE3 (AAN57126) & Shewanella oneidensis & [103] \\
\hline & SYE4 (AAN56390) & Shewanella oneidensis & [103] \\
\hline \multirow{3}{*}{ Actinobacteria } & OYERo2 (ALL54975) & Rhodococcus opacus 1CP & [22] \\
\hline & Nox (ALG03744) & Rhodococcus erythropolis & [72] \\
\hline & PfvC (AFF18622) & Arthrobacter sp. JBH1 & [71] \\
\hline \multirow{3}{*}{$\begin{array}{l}\text { Bacteroidetes/ } \\
\text { Flavobacteria }\end{array}$} & Chr-OYE1 (ALE60336) & Chryseobacterium sp. CA49 & [73] \\
\hline & Chr-OYE2 (ALE60337) & Chryseobacterium sp. CA49 & [73] \\
\hline & Chr-OYE3 (AHV90721) & Chryseobacterium sp. CA49 & [74] \\
\hline \multirow{6}{*}{$\begin{array}{l}\text { Firmicutes/(Bacilli, } \\
\text { Clostridia) }\end{array}$} & YqjM (BAA12619) & Bacillus subtilis strain 168 & [75] \\
\hline & YqiG (BAA12582) & Bacillus subtilis strain 168 & [104] \\
\hline & GkOYE (BAD76617) & Geobacillus kaustophilus DSM7263 & [76] \\
\hline & GeoER (BAO37313) & Geobacillus sp. 30 & [105] \\
\hline & LacER (ADK19581) & Lactobacillus casei str. Zhang & [10] \\
\hline & TOYE (ABY93685) & Thermoanaerobacter pseudethanolicus E39 & [77] \\
\hline
\end{tabular}


Table 2. Cont.

\begin{tabular}{lccc}
\hline \multicolumn{1}{c}{ Group/Order } & Enzyme (Ncbi Accession) & Source & Reference(s) \\
\hline \multirow{2}{*}{ Deinococcus-Thermus } & TsOYE (CAP16804) & Thermus scotoductus SA-01 & {$[79]$} \\
& DrER (AAF11740) & Deinococcus radiodurans R1 & {$[80]$} \\
\hline & GloeoER (BAC91769) & Gloeobacter violaceus PCC7421 & {$[81]$} \\
& CyanothER1 (ACK64210) & Cyanothece sp. PCC 8801 & {$[81]$} \\
& CyanothER2 (ACK65723) & Cyanothece sp. PCC 8801 & {$[81]$} \\
Cyanobacteria/ & LyngbyaER1 (EAW37813) & Lyngbya sp. PCC 8106 & {$[81]$} \\
(Gloebacteria, & AcaryoER1 (ABW29811) & Acaryochloris marina MBIC11017 & {$[81]$} \\
Oscillatoriophycidea, & AcaryoER3 (ABW32756) & Acaryochloris marina MBIC11017 & {$[81]$} \\
Nostocales) & SynER (ABB56505) & Synechococcus elongatus PCC 7942 & {$[21]$} \\
& NospuncER1 (ACC84535) & Nostoc punctiforme PCC 73102 & {$[81]$} \\
& NostocER1 (BAB73564) & Nostoc sp. PCC 7120 & {$[81]$} \\
\hline
\end{tabular}

Colours are assigned based on a new classification according to the dendrogram in Figure 2. Yellow (class I) contains classical OYEs originating from bacteria. Green (class III) contains thermophilic-like OYE homologues originating from bacteria. Non-highlighted OYEs could not be assigned to classes I-III.

The discovery of a second OYE subclass twelve years ago led Macheroux and co-workers to publish the structure of YqjM, an OYE from the Bacillus subtilis strain $168[75,106]$. In contrast to all other OYEs known at the time, YqjM exhibited unique structural properties, such as its occurrence as a homotetramer, and the presence of an arginine at the $C$-terminus involved in the substrate binding of the adjacent monomer. Next, the thermostable TsOYE (formerly $\mathrm{CrS}$ ) and TOYE were isolated from Thermus scotoductus SA-01 and Thermoanaerobacter pseudethanolicus, respectively [77-79]. Based on a sequence alignment of known and putative OYE homologues from mesophilic and thermophilic organisms, the renaming of the "YqjM" subclass into the "thermophilic-like" was proposed by Scrutton and co-workers in 2010 [77-79]. Subsequently, the number of characterised OYEs in this subclass has risen to sixteen (Table 2, highlighted in green).

OYEs from the thermophilic-like class possess shorter protein sequences (between 337 and 371 amino acid residues) than classical OYEs (between 349 and 412 amino acid residues). Thermophilic-like OYEs have an average increased thermal stability compared to classical ones. High melting temperatures were observed for TsOYE $\left(T_{\text {opt }}=65^{\circ} \mathrm{C}[79]\right)$, TOYE $\left(T_{\mathrm{m}}>70^{\circ} \mathrm{C}[77]\right)$, GkOYE $\left(T_{\mathrm{m}}=76-82{ }^{\circ} \mathrm{C}[76]\right)$, GeoER $\left(T_{\text {opt }}=70{ }^{\circ} \mathrm{C}\right.$ [105]), and FOYE-1 $\left(T_{\text {opt }}=50^{\circ} \mathrm{C}\right.$ [23]). The thermostability of TsOYE and TOYE was assigned to a high proline content within loops and turns (typical for Thermus species) as well as to strong inter-subunit interactions through hydrogen bonding and complex salt bridge networks at the dimerization interface [77,78].

We recently described FOYE-1 as a thermostable OYE [23]. Surprisingly, FOYE-1 showed highest sequence identity ( $55 \%$ and $50 \%$ ), and therefore closest phylogenetical relationship, to the mesophilic counterparts RmER and DrER [23]. DrER and RmER are not an exception with respect to the non-thermostable OYE relatives YqjM, XenA, and OYERo2, all clustering in the thermophilic-like subclass. These OYEs have a proline content below $7 \%$, and are mostly stabilized through single salt bridges. Due to these varieties in the thermophilic-like subclass, we suggest the classification be updated through a phylogenetic analysis of all biochemically characterized OYEs (Figure 2). 


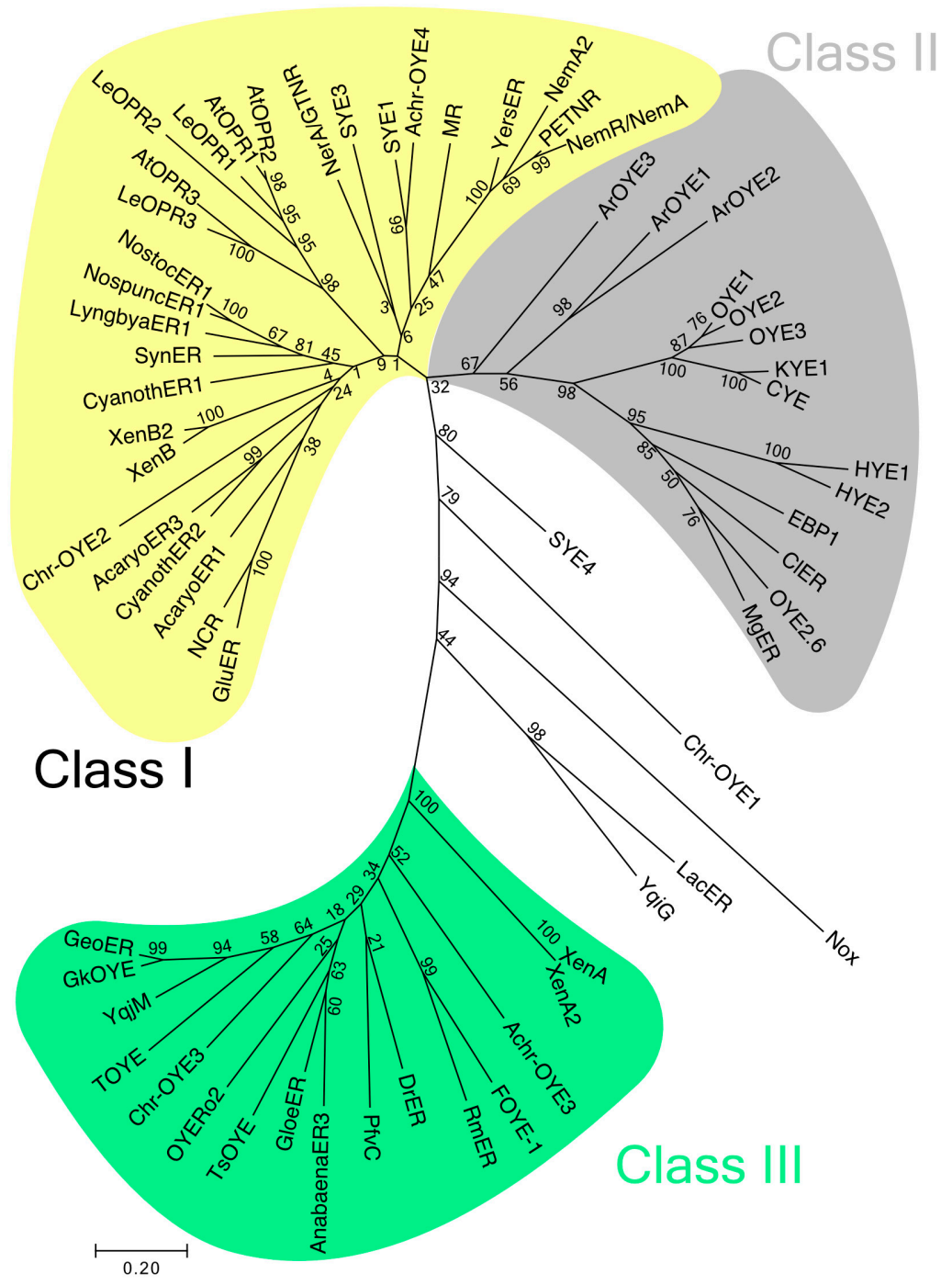

Figure 2. Dendrogram showing the relationship of 63 characterised OYEs from plants, fungi and bacteria. Corresponding accession numbers and sources are given in Tables 1 and 2. Class I (yellow) contains classical OYEs originating from plants and bacteria. Class II (grey) contains classical OYEs originating only from fungal species. Class III (green) contains the thermophilic-like and mesophilic OYEs originating from various bacteria. The maximum likelihood distance tree (Mega7-mac computed) was calculated with replications of 500 bootstraps. Corresponding values are shown as nodes at all branches. The corresponding alignment was produced via ClustalW alignment applying the GONNET protein weight matrix.

Calculating the phylogenetic distance tree of 63 characterised OYEs revealed three instead of two comprehensive branches (Figure 2). Branch 1 (highlighted in yellow) contains many classical OYEs from plants, actino- and proteobacteria, flavobacteria, but also another distinct subclade from cyanobacteria. We designate this branch "class I". Branch 2 ("class II", highlighted in grey) appears closely related to branch 1 and contains exclusively classical enzymes from fungi. Branch 3 ("class III", highlighted in green) is further away from branch 1 and 2 and contains-like class I-not only bacterial OYEs from actino-, proteo- and cyanobacteria, but also OYEs from deinococci, flavobacteria and firmicutes. This branch contains the traditional thermophilic-like OYEs. Furthermore, several sequences (SYE4, Chr-OYE1, Nox, LacER and YqiG) occurred in a position where they cannot be assigned yet. They may represent evolutionary intermediates/predecessors of class I and class III enzymes as they are of bacterial origin. The short distance between class I and class II hints towards a 
close relatedness and therefore a co-driven evolution. Our phylogenetic analysis allowed no distinction between thermostable and non-thermostable OYEs within class III since thermostability does not display a logical pattern.

Among conventional phylogeny methods, we considered the amino acid composition of all analysed OYEs regarding their early/simple (particularly Ala, Thr, and Val) and late/sophisticated (particularly Cys, Leu, Phe, Trp, and Tyr) amino acid residues [107,108]. The quotient of late over early amino acids was used to determine a comparable time of evolvement factor. Therefore, a low number represents a primary chain mostly containing early/simple amino acids. Regarding the OYEs from class I without the subclade from cyanobacteria, an average factor of 0.76 was determined. By contrast, class II's average factor amounted to 0.94 . This result would indicate a successive evolution during which class II evolved from class I. However, the more remote class III could have evolved in a convergent evolution with class I since the average factor was similar (0.77). The convergent evolution hypothesis is strengthened by the difference in average amino acid length as well as by the biochemical and structural properties, which both differ among class I and class III. OYEs from cyanobacteria (included in class I) seem also to be recruited later due to the average factor of 0.88 . To intensify this finding, main properties of class I, II and III regarding their sequences and structures are discussed in the following section dealing with the structural classification of those three classes. Furthermore, this information enables to subclassify class III OYEs and to assign the lost proteins SYE4, Chr-OYE1, Nox, LacER and YqiG to one of the three classes or to confirm their independent status, respectively.

\section{Structural Classification of OYEs: From Sequence to Structure}

OYE homologues show high conservation of amino acids involved in the binding of flavin, substrates and/or inhibitors, as well as for those involved in the formation of the dimeric interface. However, there are many differences in the conservation of distinct residues depending on the class of OYEs mentioned above. A multiple sequence alignment was performed with five representative sequences from each class (Figure S1). This section compares the sequences of OYE classes I-III enzymes and discusses the significant effects on the structure of OYEs.

\subsection{Multiple Sequence Alignment}

Approximately 15\% (56 amino acids (aa)) are OYE-conserved residues in all three classes (Figure S1, highlighted in black). Moreover, 40 additional aa are conserved especially in class I (highlighted in yellow), 32 aa in class II (highlighted in grey) and 43 aa in class III (highlighted in green). Evidently, class I and class II share significantly more conserved residues when compared to class III, resulting in the minor distance (Figure 2).

The alignment including the five non-assignable sequences also allows matching of these OYE enzymes with the defined classes. The sequences SYE- 4 and Chr-OYE1 are more closely related to class I since they share $63 \%$ and $45 \%$ of the class I conserved residues but only $34 \%(25 \%)$ for class II and $9 \%(21 \%)$ for class III, respectively. Nox and YqiG are more related to class III, sharing $37 \%$ and $40 \%$ of class III conserved residues whereas they jointly own only $23 \%(34 \%)$ of class I, and $25 \%(19 \%)$ of class II conserved residues. LacER shares 39\% (class I), 19\% (class II) and 30\% (class III) and is somewhere in between. Interestingly, all five proteins do not possess the Cys26 and the Arg336 (YqjM numbering), which are highly conserved in class III and are involved in flavin and substrate binding. The alignment shows they contain many general OYE motifs. However, all of them comprise motifs from class I/II but also from class III generating a reasonable alignment in between of classes I-III. Therefore, small substitutions of essential amino acids may change binding properties or oligomeric state performance making those enzymes promising candidates for bioengineering.

\subsection{Monomeric Structure and Dimeric Interface}

Members of the OYE family were found to exist in different oligomeric states. A remarkable property observed for class III OYEs is their occurrence in solution as homodimers and 
homotetramers [22,76,105]. Even higher species as octamers and dodecamers, emerged from functional homodimers, were observed for TOYE and TsOYE $[77,79]$. A shift between higher multiple oligomeric states was noticed depending on the protein concentration [22,77]. On the other hand, members of class I and class II were found to exclusively occur as monomers or homodimers $[14,83,109]$. Nevertheless, the basic monomer structure is very similar. A typical single domain is represented by an $(\alpha, \beta)_{8}$-barrel structure (TIM barrel) with additional secondary structure core elements, in which FMN is bound at the $C$-terminal end (Figure 3). Secondary structure prediction showed that these core elements are similar in location and length in all three classes (Figure S1, SecStruc). An $N$-terminal hairpin of two short $\beta$-strands ( $\beta A$ and $\beta B$ ) builds the bottom of the barrel prior to strand $\beta 1$ (OYE1 numbering) (Figure 3, blue hairpin) $[75,78,83]$.

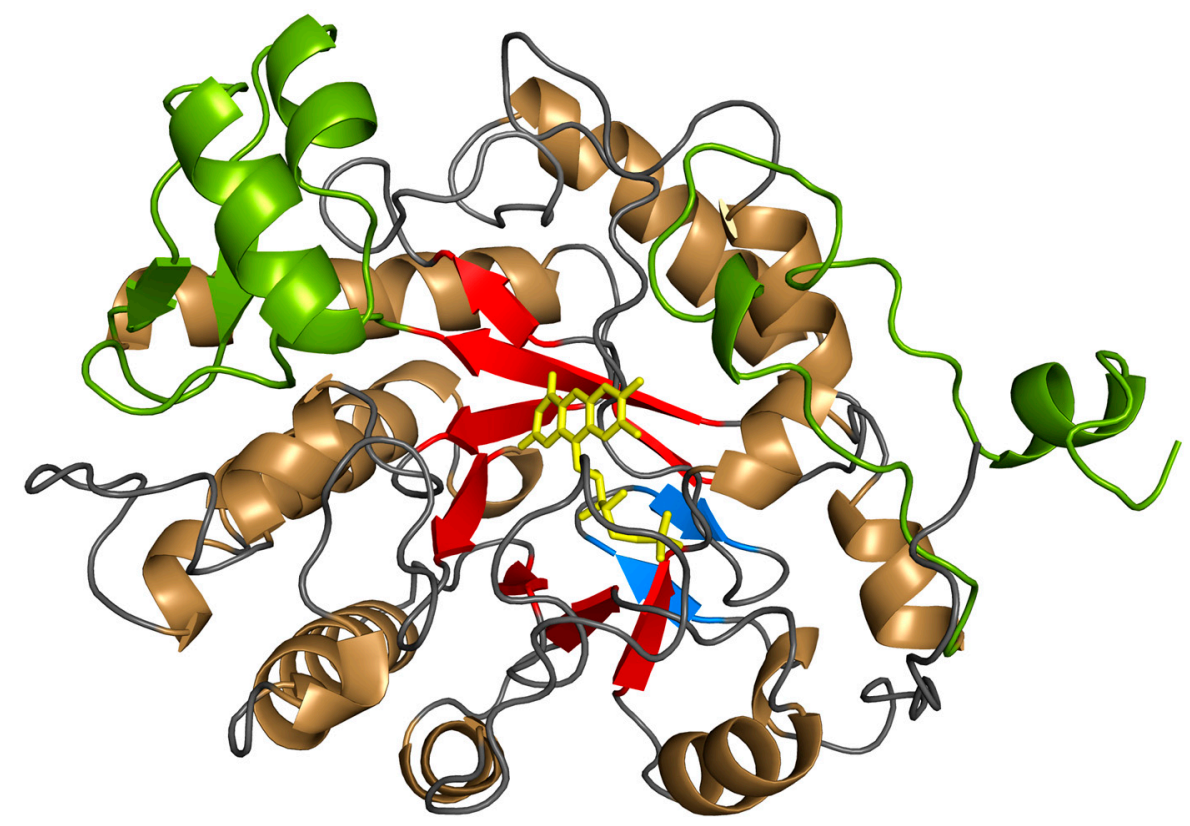

Figure 3. TIM-barrel structure of OYEs. Three-dimensional model of the crystal structure of Saccharomyces pastorianus OYE1 (pdb entry: 1OYA). The $\alpha$-helices and $\beta$-strands of the TIM-barrel are indicated in gold and red, respectively. The $N$-terminal hairpin of two short $\beta$-strands at the bottom of the barrel is indicated in blue. The $C$-terminal helices and the large surface loop between $\beta 3$ and $\alpha 3$ are indicated in green. The FMN prosthetic group is indicated in yellow.

Additional secondary structure elements occur on surface loops between core building blocks of $\beta$-strands and $\alpha$-helices. The largest loop occurs between $\beta 3$ and $\alpha 3$ and differs greatly between all OYE representatives (Figure 3, green surface loop) $[75,78,83]$. Class III enzymes are up to 40 amino acids shorter and therefore more compact. This is due to the shortening of the $N$-terminal surface loops between $\beta 3$ and $\alpha 3$, but also between $\beta 5$ and $\alpha 5$ and at the $C$-terminal end of the protein (Figure S1). However, the capping domain between $\beta 3$ and $\alpha 3$, which is partly covering the entrance of the active site, differs greatly in length and type of structural units within subclass III [78]. Each monomer within the functional dimer is facing the central hole with the same side and contributes the same residues to the hydrogen bond network that keeps monomers together [77]. Residues Gln330 and Tyr331 (TOYE numbering) are highly conserved and seem to play a role in monomer interaction [77]. While Gln330 is specific for class III enzymes, Tyr331 is conserved for all OYEs (Figure S1). A variety of additional residues assist in the formation of the functional dimer-dimer interface such as Thr45, Ser28/His42/Arg46 and Tyr315 (TOYE numbering) [77,78]. Many of them are conserved only for class III enzymes. The most influential factor for the formation of the functional dimer-dimer interface of class III is Arg333 (TOYE numbering). This "arginine finger" stretches into the active site of the 
adjacent monomer and interacts with the respective flavin cofactor. An additional stabilization of some class III enzymes originating from extremophiles is associated with an increased proline content of surface loops [23,78], and with the presence of three complex salt bridge networks at the dimerization interface that increases the subunit interaction strength. The complex five residue salt bridge between four residues of $\alpha 2$ and an asparagine from $\alpha 1$ is not conserved for class III enzymes. However, incorporation of this salt bridge within another class III enzyme by site-directed mutagenesis indeed increased the thermal stability [22].

\subsection{FMN Binding}

The FMN prosthetic group is bound at the $C$-terminal end of the $\beta$-strands, a typical location for the active sites of TIM-barrel enzymes (Figure 3) [110]. The re side of the flavin is facing the protein and is completely hidden from the active site but in contact with strand $\beta 1[111,112]$. The si side of the flavin is facing a solvent filled access channel (20 A length in PETNR) and therefore forms the bottom of a wide-open active pocket mainly assembled with aromatic residues [9]. The redox potential of the FMN cofactor is controlled by the different interactions between the protein and the flavin. The N3 and $\mathrm{O} 2$ atoms of the flavin pyrimidine ring are interacting with a glutamine (Gln102 in YqjM) and the N1 and O2 with an arginine (Arg215 in YqjM) (Figure 4) [75]. Both residues are strictly conserved in OYEs. Furthermore, a conserved histidine pair is described for all OYEs to be in hydrogen bonding distance. In YqjM (class III), His167 and His164 donate a hydrogen bond for the N1 or N3 atom of the flavin, respectively (Figure 4) [75]. However, in PETNR (class I) the pursuant histidines (His184 and His181) donate the hydrogen bond to the flavin $\mathrm{O} 2$ as well as to the activating group of the substrate/inhibitor [111]. While both histidines are highly conserved in class III, the second histidine is replaced by an asparagine in several class I and class II enzymes (Figure 4 and Figure S1). For example, the corresponding asparagine (Asn194) in OYE1 is known to play a key role in ligand binding [83,111]. Moreover, residues Ala60 and Cys26 (YqjM) were found to be in hydrogen bonding distance to the FMN O4 atom (Figure 4) [75]. While Ala60 is conserved within all classes (sometimes glycine in class II), the cysteine residue is a unique feature only for class III enzymes. Cys26 was shown to interact not only with the O4-atom of the flavin but also with Tyr28 (Figure 4), which is also conserved in class III. In class I/II, Cys26 is replaced by a conserved threonine (Thr37 in OYE1), which is as well within hydrogen bonding distance to the O4-atom of the isoalloxazine ring [112]. It was shown that both residues modulate the flavin reduction potential after they were exchanged by mutagenesis [112-114].

The dimethylbenzene moiety of the flavin isoalloxazine ring was described to interact with the hydrophobic residues Met25, Leu311 and Arg308 (YqjM [75]). The methionine is conserved only for class III enzymes as well as the leucine, which is replaced by isoleucine in class I/II. The arginine is also highly conserved for class II but not for class I enzymes. In PETNR, a tyrosine (Tyr351) is in van der Waals contact with the edge of the dimethylbenzene nucleus [111]. This tyrosine is conserved for class I/II. In OYE1 the hydrophobic area around the dimethylbenzene ring is more compact and contains two interacting phenylalanine residues (Phe250 and Phe296). Phe250 is highly conserved in class II enzymes but also occurs in PETNR (Phe240). However, Phe296 is neither conserved in class I nor in class II. Instead of the phenylalanines, class III enzymes possess an arginine (Arg336 in YqjM), a residue involved in both, flavin binding and formation of the dimeric interface (vide supra).

The ribityl chain of the flavin is stabilized in all classes by a conserved proline and an arginine (Pro24 and Arg215: YqjM numbering). Additionally, class III enzymes were also found to anchor the cofactor in this part to Ser23, Ser249 and Gln265 (YqjM numbering) [75]. However, Figure S1 shows that Ser23 is not conserved in class III OYEs, as previously published [9]. 


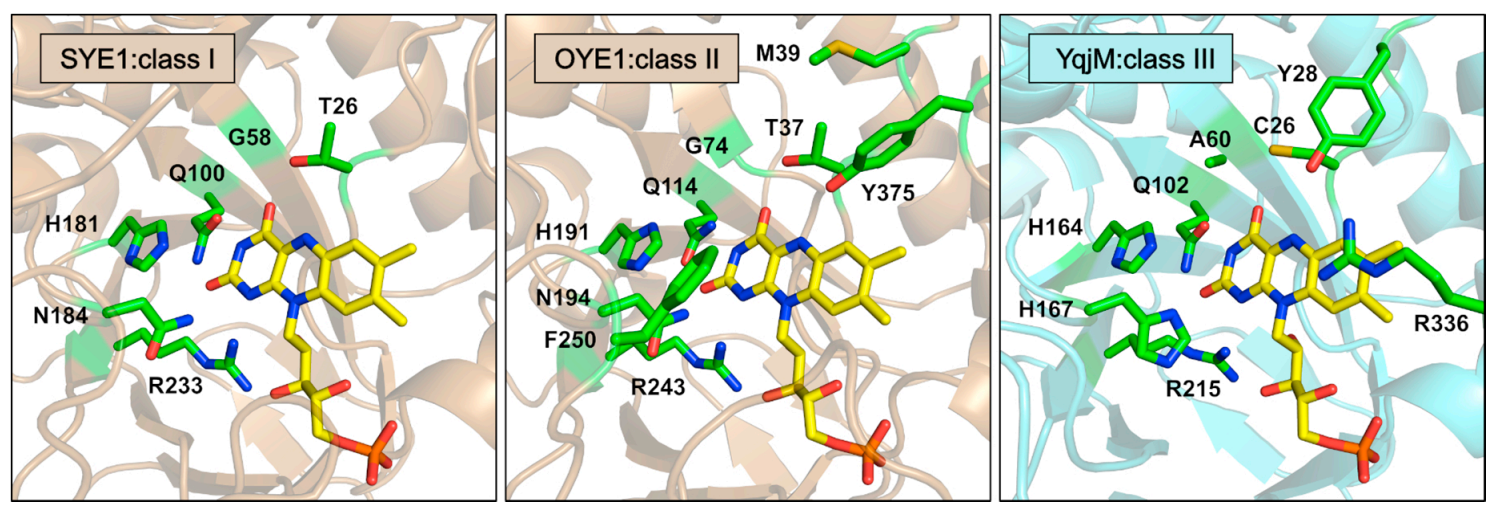

Figure 4. Active site of SYE1 (pdb entry: 2QG9; class I) from Shewanella oneidensis, OYE1 (pdb entry: 1OYA; class II) from Saccharomyces pastorianus and YqjM (pdb entry: 1Z41; class III) from Bacillus subtilis. The side chains interacting with the flavin in the active site are shown in stick models and coloured by elements (red = oxygen-containing group; blue = nitrogen containing group). The FMN cofactor is shown as stick model and coloured by elements with carbons in yellow. Class I and class II proteins have very similar active sites and are shown in metallic brown. The class III protein is shown in metallic blue. Note that R336' in YqjM belongs to the adjacent subunit. The rms distances (rmsd) were obtained from overlaid structures (see Figure S2) between SYE1 and OYE1 (0.667 ̊̊), SYE1 and YqjM (1.055 $)$ ), and OYE1 and YqjM (1.262 ̊̊).

\subsection{Coenzyme and Inhibitor Binding}

In co-crystallisation studies of OYEs, the $F_{\mathrm{O}}-F_{\mathrm{c}}$ electron density map of the uncomplexed, oxidized enzyme gives a strong positive peak above the flavin isoalloxazine ring. This observation is due to the binding of an anion from the crystallisation solution such as sulphate [75], chloride [83,111], acetate or formate [77]. Addition of NADPH resulted in the replacement of the sulphate by two water molecules and in the reduction of the flavin [75]. In agreement with a bi-bi ping-pong mechanism, great similarity exists among OYEs in the binding mode of the nicotinamide moiety of NADPH and phenolic inhibitors such as para-hydroxybenzaldehyde ( $p$-HBA) (Figure 5) or para-nitrophenol ( $p$-NP). Both aromatic rings are oriented through $\pi-\pi$ stacking with the FMN isoalloxazine ring and hydrogen bonding with His167/Asn194 and His164/His191 (YqjM/OYE1) [115]. The crystal structure of OYE1 (class II) with an $\mathrm{NADP}^{+}$analogue showed that the oxygen of the amide on the pyridinium ring is (hydrogen) bonding with the two conserved histidine residues, thus positioning the $\mathrm{C} 4$ atom close to the N5 atom of FMN for the hydride transfer [83]. The same position was observed for the nicotinamide ring of tetrahydro-NADH in MR (class I) (Figure 5) and TOYE (class III) [77,116].

Analogues of histidine/asparagine residues are found in all classes of OYE homologues. A remarkable difference is the binding of the functional group of the phenolic ligand. For instance the aldehyde group of $p$-HBA interacts with Tyr375 (OYE1) [83], or Tyr351 (PETNR) [75], respectively. This tyrosine residue is conserved within all OYE classes (Figure S1), but was never mentioned to play a role in the catalysis of class III enzymes, which use a different strategy to build their active sites. A reorientation of the $C$-terminal end causes the formation of a part of the active site of the adjacent monomer. Therefore, only an arginine (Arg333 in TOYE) contributes to the opposed active site. The "arginine finger" causes the formation of a strong hydrogen bond with the nitro-group of $p$-NP [75], or the O1P/O1N atoms of tetrahydro-NADH [77]. Replacement of this arginine might be a biocatalytic tool to broaden/change the substrate spectrum or cofactor specificity of class III enzymes. Another $\mathrm{N}$-terminal class III conserved tyrosine (Tyr28 in YqjM) is involved in binding of the aldehyde oxygen of $p$-HBA $[75,78]$. Furthermore, Tyr175/Tyr196 (TsOYE/OYE1) was confirmed to be a proton donor for the substrate 2-cyclohexenone [75,78], and is conserved within all subclasses. To summarize, the binding partner for the functional group of aromatic substrates is always a tyrosine, which is in hydrogen bonding distance. Class I and class II use two tyrosines from the central part (Tyr196 in 
OYE1) and the C-terminal protein part (Tyr375 in OYE1), whereas class III enzymes involve the central part tyrosine (Tyr175 in TsOYE) as well, but a second $\mathrm{N}$-terminal tyrosine (Tyr25 in TsOYE) takes over the role of the class I/II C-terminal tyrosine due to reorientation.
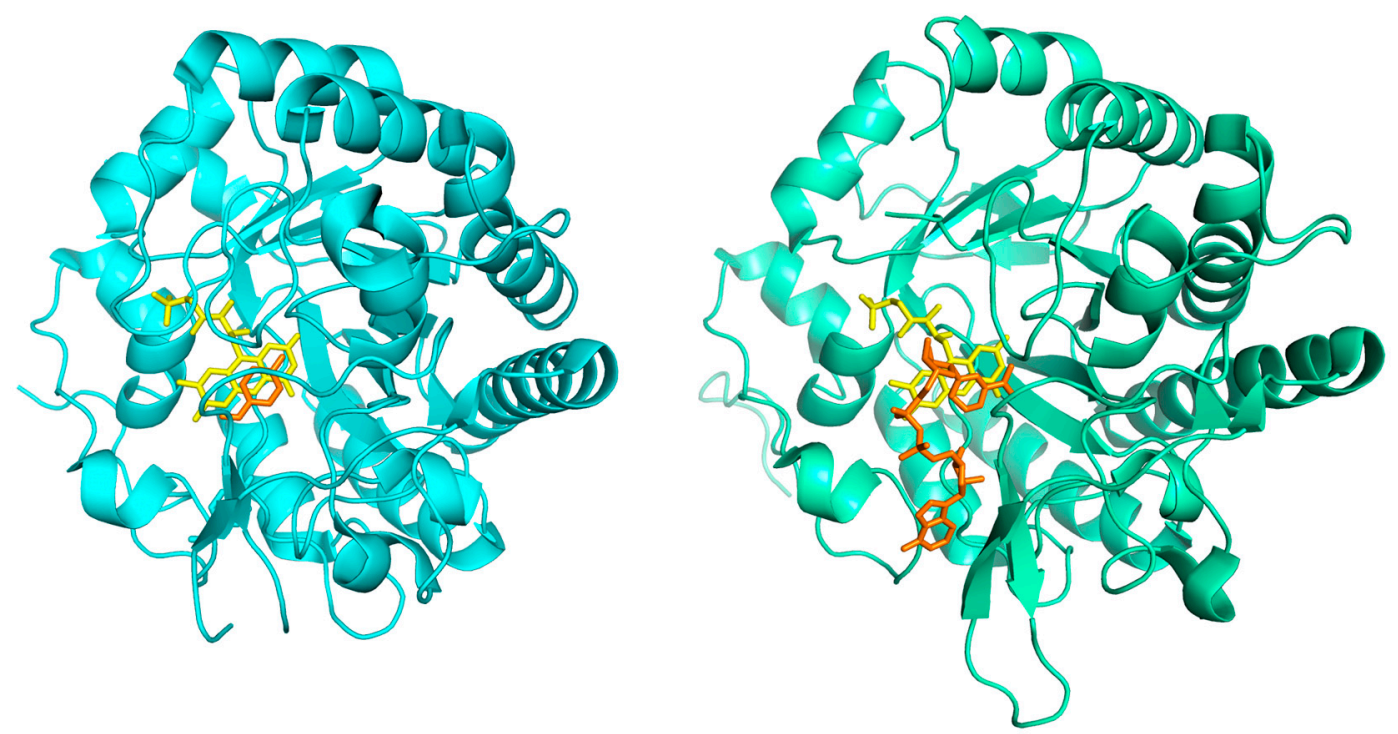

Figure 5. Ligand binding in OYEs: (Left) NADH:flavin oxidoreductase from Shewanella oneidensis (SYE1) with para-hydroxybenzaldehyde bound (pdb entry: 2GQ9). The protein is shown in blue cyan, the flavin cofactor in yellow, and the phenolic inhibitor in orange. (Right) morphinone reductase (MR) from Pseudomonas putida with tetrahydro-NAD bound (pdb entry: 2R14). The protein is shown in green cyan, the flavin cofactor in yellow, and the pyridine nucleotide in orange.

The majority of OYEs display a preference for NADPH over NADH as the source of hydride, as indicated from catalytic efficiencies $\left(k_{\mathrm{cat}} / K_{\mathrm{M}}\right)$ or apparent dissociation constants $\left(K_{\mathrm{D}}\right)$. The specificity ratio of NADPH:NADH, obtained from specific activity with trans-2-hexenal by Bruce and co-workers [117], can vary from 0.02 (MR) to 10 (OYE1), although the cofactor preference for KYE1, XenA and Yers-ER was shown to differ depending on the substrate, yielding different NADPH:NADH specificity ratios, a surprising result given the bi-bi ping-pong mechanism described above [6]. Interestingly, TsOYE displays a similar $K_{\mathrm{D}}$ for $\mathrm{NADPH}$ and $\mathrm{NADH}$, but a five times higher reaction rate when using NADPH with respect to NADH [59]. The only OYEs displaying a higher affinity for NADH are from class I: NerA/GTNR [98], MR [85], SYE1 and SYE3 [103]. LacER, which falls short of being assigned to a class, although the closest class it relates to seems to be class I as seen above, also shows a preference for NADH [10].

The group of Hauer recently showed examples of grafted $\beta / \alpha$ surface loop regions between OYEs MR, NCR and OYE1 that led to altered as well as new reaction activities and a change in NADH interactions [118-120]. One example was showcased with NCR (class I), which displayed lower activity with increasing $\mathrm{NAD}^{+}$present in the reduction reaction of cinnamaldehyde [118-120]. Through $\beta / \alpha$ surface loop grafting from OYE1 (class II) and MR (class I) to form various loop variants of NCR, the loss of activity with higher presence of $\mathrm{NAD}^{+}$was significantly reduced [118-120].

\section{Reactivity with NCBs}

Recently, as mentioned above, NCBs 1-7 in Figure 1 were used as alternative hydride source to replace $\mathrm{NAD}(\mathrm{P}) \mathrm{H}[23,52,58,59]$. Kinetic data with NCBs (1-5) are available for PETNR (class I), and for TOYE, XenA, and TsOYE (class III). Additionally, biocatalytic reactions were performed and conversion data were acquired for class I (yellow): PETNR, LeOPR1, XenB, MR, and NerA; class II (grey): OYE2 
and OYE3; and class III (green): XenA, TOYE, TsOYE, DrOYE, and RmOYE (Figure 6) [59]. Other NCBs (6-7) were also screened with MR, NCR, OYE1 and OYE3 [58].
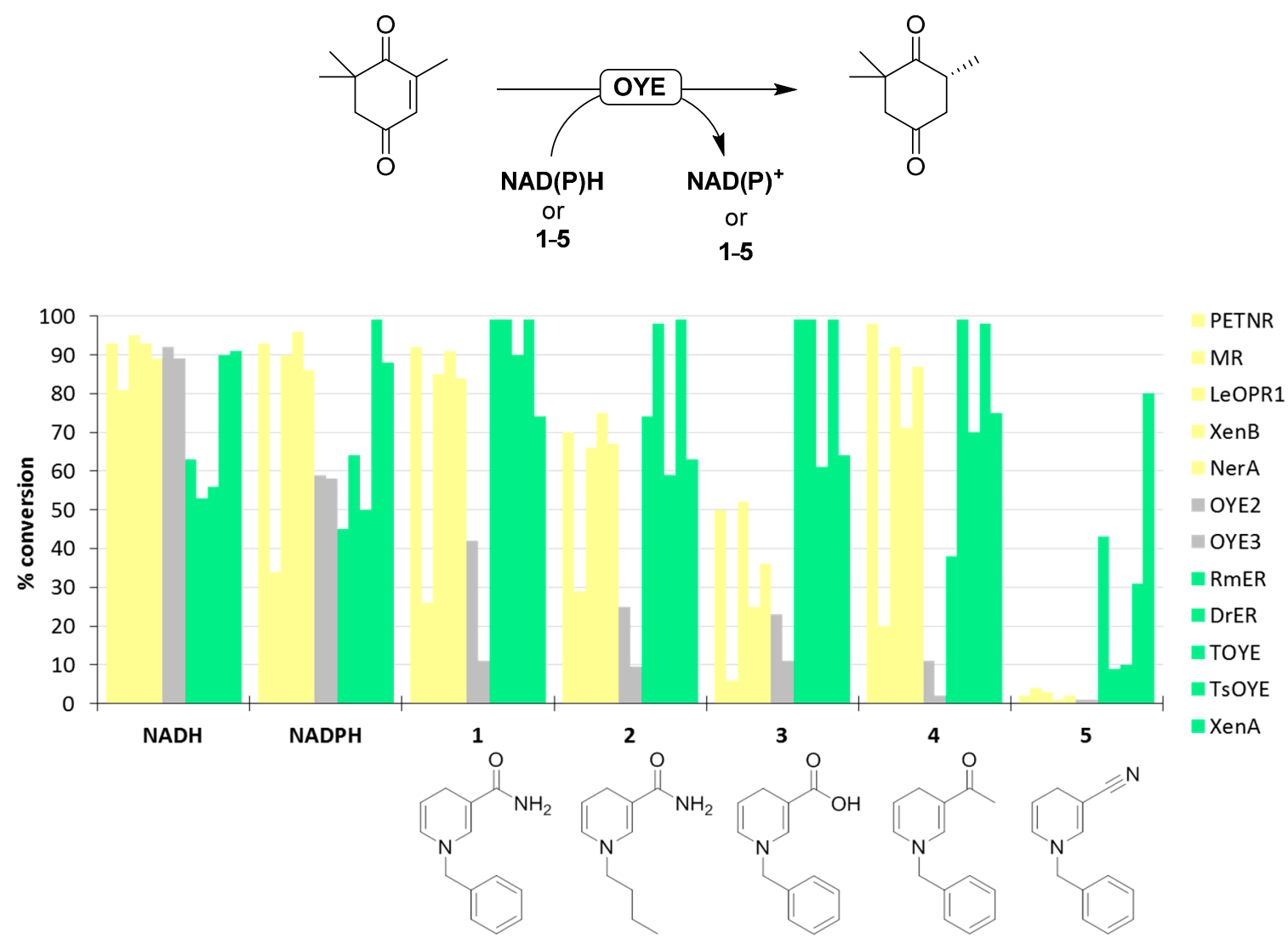

Figure 6. Asymmetric hydrogenation of ketoisophorone to (6R)-levodione with a panel of OYEs from class I (yellow), II (grey) and III (green) and NCBs 1-5 (1-benzyl-1,4-dihydronicotinamide 1, 1-butyl-1,4-dihydronicotinamide; 2, 1-benzyl-1,4-dihydronicotinic acid 3, 1-benzyl-3-acetyl1,4-dihydropyridine 4, and 1-benzyl-3-cyano-1,4-dihydropyridine 5) (data adapted from [59]).

\subsection{Biocatalytic Conversions}

From the full biocatalytic reaction for the reduction of the model substrate ketoisophorone, moderate to high conversions were obtained with NADPH and NADH and low to high conversions with NCBs 1-5 (Figure 6) [59]. NCB 5 gave very low conversions (1-10\%), except for XenA (80\%), TsOYE (59\%) and RmER (43\%) [59]. With our new classification, we noted the enzymes accepting NCB 5 were all from class III, and that OYE2-3 from class II gave lower conversions with the NCBs in general.

\subsection{Kinetic Data: Steady State and Pre-Steady State}

The reduction of 2-cyclohexenone under steady-state conditions gave $k_{\mathrm{cat}}, K_{\mathrm{M}}$ and catalytic efficiency $k_{\mathrm{cat}} / K_{\mathrm{M}}$ for PETNR (class I), TOYE and XenA (class III) [59]. Noting that class III TOYE and XenA gave the highest rates with the NCBs, XenA in particular displayed high catalytic efficiency $\left(k_{\text {cat }} / K_{\mathrm{M}}\right)$ with NCB 2 (Figure 7). 


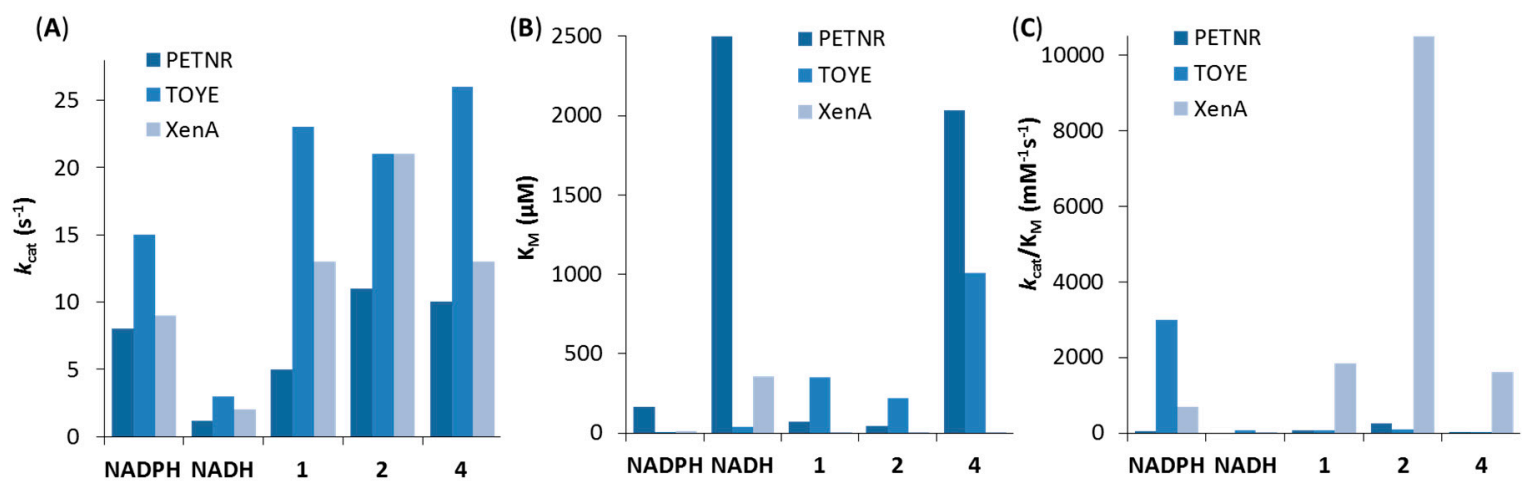

Figure 7. Steady-state kinetics with: catalytic activity $k_{\text {cat }}(\mathbf{A})$; Michaelis constant $K_{\mathrm{M}}(\mathbf{B})$; and catalytic efficiency $k_{\mathrm{cat}} / K_{\mathrm{M}}(\mathbf{C})$ for the reduction of 2-cyclohexenone to 2-cyclohexanone by PETNR, TOYE and XenA with NCBs 1, 2 and 4 (data adapted from [59]).

The rates of the reductive half-reaction showed that PETNR from class I displayed lower rates when compared to TOYE, XenA and TsOYE from class III (Figure 8A,B) [59]. TOYE gave the highest reduction rates followed by XenA and TsOYE. NCB 3 clearly afforded the highest reduction rate values, but also the highest dissociation constant $K_{\mathrm{D}}$ for the enzyme-reduced nicotinamide complex (Figure 8C,D). For each OYE, the order of the best to poorer NCB differed (Figure 8A,B).
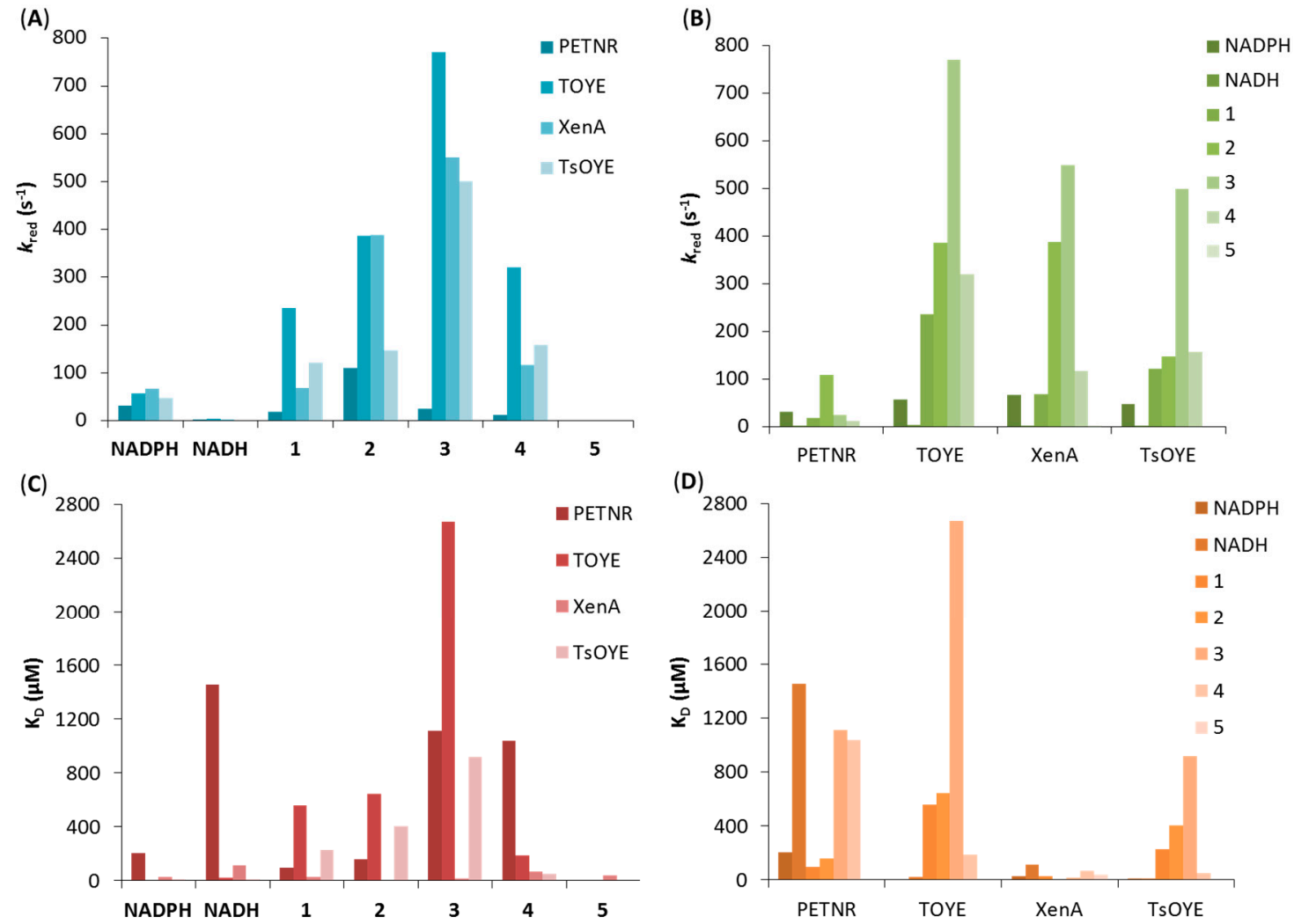

Figure 8. Reduction reaction rates $k_{\text {red }}(\mathbf{A}, \mathbf{B})$; and dissociation constants $K_{\mathrm{D}}(\mathbf{C}, \mathbf{D})$ for the reductive half-reaction of PETNR, TOYE, XenA and TsOYE and NCBs 1-5 (data adapted from [59]).

Fast reaction kinetics with MR and PETNR (class I) by the group of Scrutton led to the conclusion that quantum mechanical tunnelling is crucial for the hydride transfer from the nicotinamide cofactor to FMN [121]. They proposed that sub-angstrom differences in the donor-acceptor distance affect the probability of hydride transfer [121-123]. From molecular modelling studies with TsOYE and NCBs 
1-5 [52], as well as with the crystal structures of XenA [59], the NCBs were observed to be in the correct position, $\pi$ stacking with the FMN isoalloxazine ring, and the amide oxygen within hydrogen bonding distance of the two conserved histidine residues (His181 and His178 in XenA). The exception was NCB 5, which contains a nitrile substituent in place of the amide, thus missing the oxygen and only hydrogen bonding with one of the two histidines. This analogue was used as a hydride donor by the OYEs but with less efficiency. Although the coenzyme biomimetics bind to the OYEs' active site in a similar way as $\mathrm{NAD}(\mathrm{P}) \mathrm{H}$, small changes in the orientation of the nicotinamide ring could affect the rate of hydride transfer. Indeed, different kinetic data was observed for all analogues and OYEs across the three classes. The NCB giving the highest reduction rate for one OYE, NCB 2 for PETNR (class I), was different for another OYE, NCB 3 for TOYE, XenA and TsOYE (class III) [59].

The overlaid crystal structures of XenA (from P. putida II-B, class III) with the tetrahydro form of cofactors $\mathrm{NADPH}_{4}$ and NCB 1-2,4 showed only minimal changes. One exception in all three NCBs structures was the alternative conformation of the tryptophan residue (Trp302 in XenA), which reduced the volume of the active site [59].

\section{Classification of OYEs with Respect to Substrates}

As listed in the introduction, OYEs can reduce a variety of $\alpha, \beta$-unsaturated activated alkene substrates, which are continuously being extended with new activating groups explored for industrial purposes. In general, the review by Toogood, Gardiner and Scrutton gives an overview of substrate family scopes for OYEs [9]. Looking at the compilation of substrates, there is a large overlap in the substrate scope and stereochemical outcome of OYEs within and across the three classes, and also wide differences within one class. Unfortunately, reported data often varies; in some cases, the specific activity was reported for each substrate, in other cases, percentage conversion of the biocatalytic reactions was reported. Furthermore, reaction times vary (4-48 h) and a range of enzyme concentrations is used, which makes identification of preferred substrates more difficult.

Selecting widely published percentages conversion of biocatalytic reactions on common substrates, we observed significant trends regarding all members of the OYE family but also noticed differences between OYE classes I-III (Figures 9 and 10). OYEs in general convert substituted (methylated) cyclic enones such as 2-methylcyclo-hexenone or -pentenone as well as 3-methylcyclo-hexenone or -pentenone. Comparing 6- and 5-membered ring substrates in Figure 9 shows that ring size is not so important with respect to biocatalytic conversions. It does, however, have a significant effect on the stereochemical outcome of the product (Figure 11). Stereochemical outcome can be influenced by the configuration of the $\mathrm{C}=\mathrm{C}$ double bond, the orientation of the substrate in the active site and the stereospecificity of the hydrogen addition [124]. For most OYEs, 2-methylcyclopentenone gave the (S)-enantiomer whereas 2-methylcyclohexenone afforded the (R)-enantiomer (Figure 11). For $\beta$-methylated substrates, the conversion was lower in all cases (classes I-III). This effect was repeatedly observed [11,12,42], and is due to steric hindrance. The formed products from $\beta$-methylated cyclic enones were (S)-enantiomers, independent from the ring size (Figure 11). Interestingly, class I enzymes display significantly lower conversions from the 2-methyl- $(80 \%)$ to the 3-methyl-cyclohexenone (20\%), whereas for class II enzymes this difference goes from $72 \%$ to $40 \%$. Class III enzymes have averaged $45 \%$ conversion of 2 -methylcyclohexenone and none of the tested enzymes were active on the $\beta$-methylated substrate. Similar values were found for substituted cyclopentenones. With $\alpha$-methylated substrates all classes gave a similar average conversion (between $48 \%$ and $63 \%$ ). For $\beta$-methyl unsaturated substrates, class III enzymes afforded no conversion, whereas the average conversion of class II enzymes is slightly higher (30\%) than that of class I enzymes $(20 \%)$. 


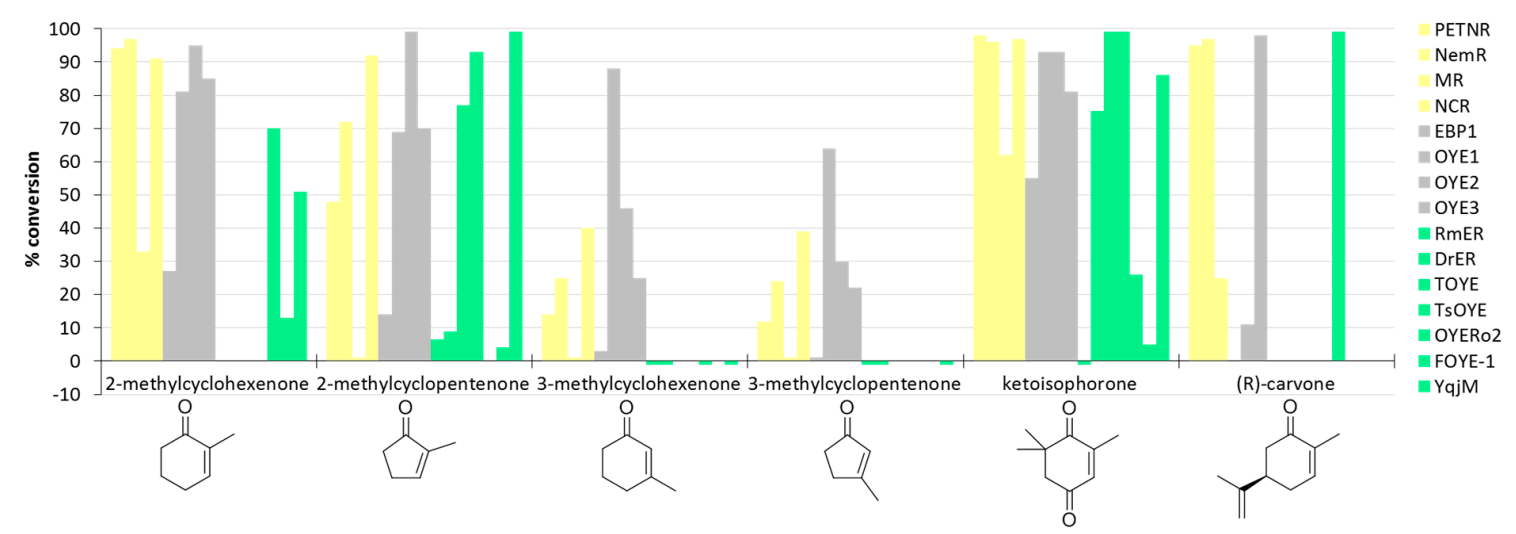

Figure 9. Cyclic enones substrate preference of OYEs according to the classification. Negative values represent conversions below 1\%. Blank spaces correspond to no measurements. References for conversion values: PETNR [44], NemR [44], MR [44], NCR [42], EBP1 [44], OYE1 [42], OYE2 [42], OYE3 [42], RmER [80], DrER [80], TOYE [77], TsOYE [52], OYERo2 [22], FOYE-1 (unpublished data) and YqjM $[12,18]$.

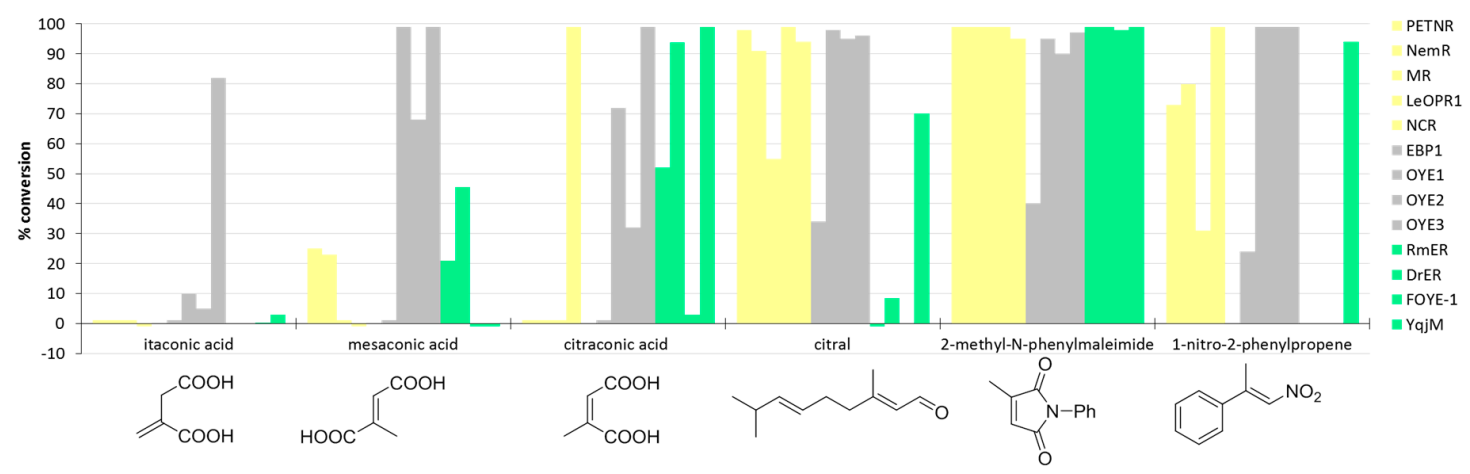

Figure 10. Dicarboxylic acids, aldehyde, maleimide, nitroalkenes substrate preference of OYEs according to the classification. Negative values represent conversions below 1\%. Blank spaces correspond to no measurements. References for conversion values: PETNR [44], NemR [44], MR [44], LeOPR1 [12,18], NCR [42], EBP1 [44], OYE1 [42], OYE2 [42], OYE3 [42], RmER [80], DrER [80], FOYE-1 (unpublished data) and YqjM $[12,18]$.

Other $\alpha$-substituted unsaturated cyclic ketones such as ketoisophorone and carvones are also alternative substrates for all three classes. However, several non-thermostable class III enzymes such as RmER, OYERo2 [22,80], and FOYE-1 (unpublished data) gave very low conversions on those substrates. Poor conversions are supported by very poor activities towards these typical substrates (ketoisophorone or cyclohexenone), mainly in class III (YqjM, FOYE-1, OYERo2, XenA, TsOYE, DrOYE, and RmOYE) [22,23]. In contrast, these enzymes showed highest specific activities on several maleimides (up to $70 \mathrm{U} / \mathrm{mg}$ ) [22,23]. Comparably, the specific activities on maleimides for classes I and II enzymes are much lower [6,8,21], but all classes reduce maleimides with high conversion yield (Figure 10). YqiG is highly active towards maleimide (56 U/mg) and shows little activity toward carboxylic acids and cyclic ketones $(<3 \mathrm{U} / \mathrm{mg})$ [104]. This non-assigned OYE exhibits high temperature stability and is closely related to class III (see Section 3). With ketoisophorone, $(R)$-carvone, 2-methyl- $N$-phenylmaleimide and 2-methylmaleimide, all investigated OYEs led to the $(R)$-enantiomer (Figure 11). In general the enantiomeric excess was lower with ketoisophorone due to known product racemisation [8]. (Dimethylated) dicarboxylic acids show remarkable differences between the three classes. Itaconic acid was only converted by class II enzymes (average conversion: $25 \%$ ). The two isomers, mesaconic acid and citraconic acid, were transformed by all three classes. 
However, class II showed on average 50\% higher conversions with respect to the other two classes and always preferred a distinct enantiomeric product: (S)-enantiomer with itaconic and citraconic acid; (R)-enantiomer with mesaconic acid. Only with the cis-substrate (citraconic acid), class III was the more active enzyme class (Figure 10). Class I enzymes exclusively led to the $(R)$-enantiomer with dimethylated dicarboxylic acids, whereas the stereochemical outcome for class III enzymes was not investigated until now. The aliphatic dimethylated dienal substrate citral was shown to be a great substrate for class I and class II. Only low to modest citral conversions were obtained within class III with YqjM and DrER (Figure 10) [12,80], as well as with TsOYE [52].

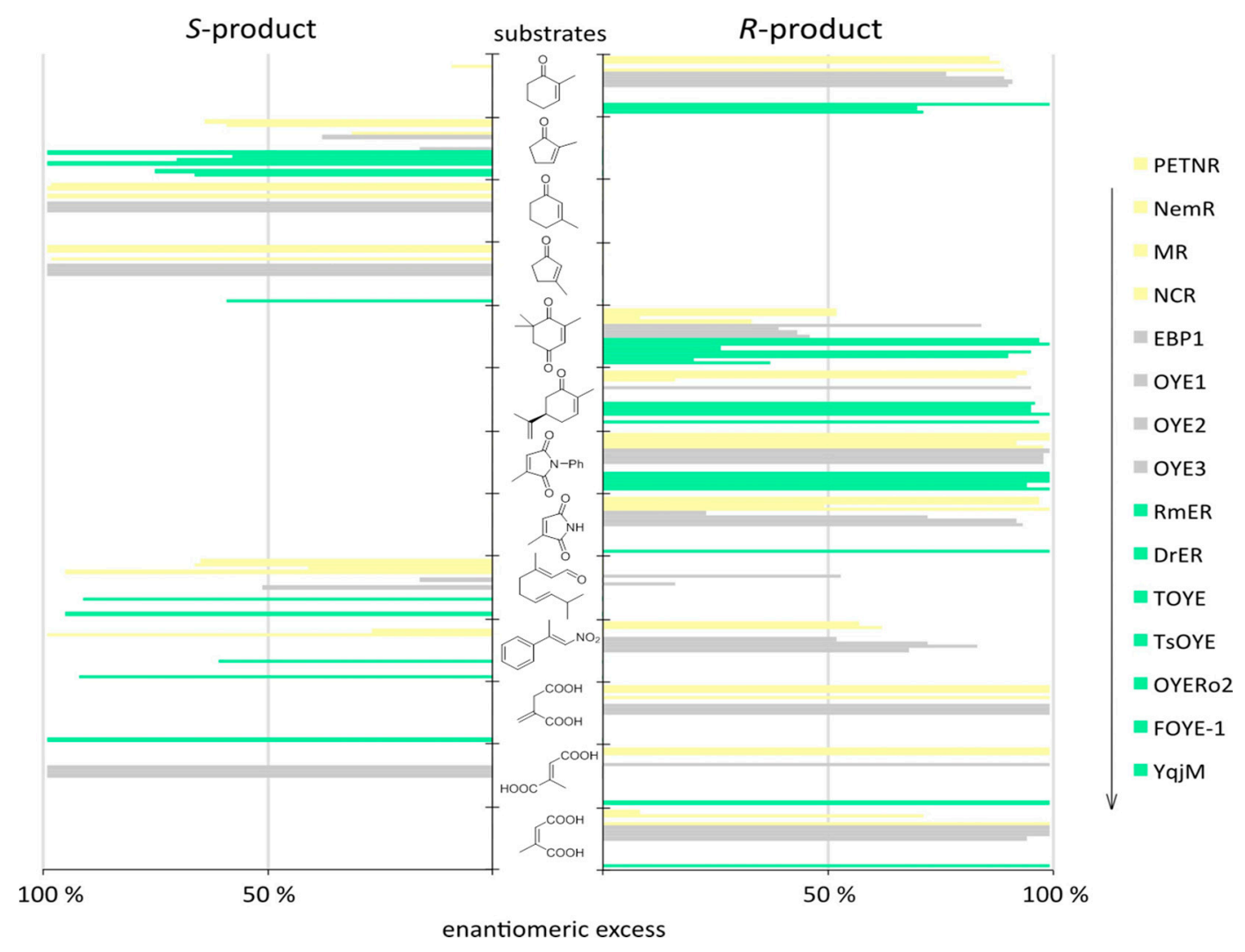

Figure 11. Stereochemical outcome of various OYE-catalysed asymmetric hydrogenations. The order of OYEs used for each substrate is from top (PETNR) to bottom (YqjM). Blank spaces correspond to no measurements. References for ee values used in this diagram: PETNR [44], NemR [44], MR [44], NCR [42], EBP1 [44], OYE1 [42], OYE2 [42], OYE3 [42], RmER [80], DrER [80], TOYE [77], TsOYE [52], OYERo2 [22], FOYE-1 (unpublished data) and YqjM [12,18].

To summarise, class I and class II prefer cyclic ketones, especially 2-methylcyclohexenone, ketoisophorone and carvones. On dicarboxylic acids, class II enzymes show best conversion rates. Maleimides are excellent substrates for the entire OYE family, class III enzymes especially, displaying remarkable activities on maleimides (about 50-times higher than on all other substrates).

A correlation between the protein structure and the sequence patterns for the stereopreference with respect to reduction of 1-nitro-2-phenylpropene was attempted to be established for 12 independent OYE structures [125]. LeOPR3, NCR, YqjM, XenA, TOYE, TsOYE, and GkOYE reduced 1-nitro-2-phenylpropene to the $S$-enantiomeric product whereas LeOPR1, OYE1, PETNR and NemR produced the $(R)$-enantiomer (Figure 11). However, the group of Pietruszka showed that the stereoselectivity of an uncharacterised OYE could not be predicted solely based on the primary sequence pattern of the surface loop $\beta 2$ [126]. 
Stereoselectivity was also investigated by the group of Stewart, who determined how subtle changes in the residues control the orientation of substrate binding in OYEs [127,128], and showed that mutations can lead to inverted enantioselectivity $[129,130]$. The stereochemical outcome was influenced by mutagenesis of Trp116 in OYE1. For instance, $(S)$-carvone displayed an inverted stereoselectivity for six different variants. The same observation was made for $(Z)-\beta$-aryl- $\beta$-cyanoacrylate when Trp116 was changed. Substitution of this amino acid against smaller residues resulted in a classical orientation of the substrate and gave the (S)-enantiomer. Substitution against more bulky residues resulted in a switch of stereoselectivity affording the $(R)$-enantiomer. This tryptophan is conserved for classes I and II enzymes and might be a major residue for changing enantioselectivity of different prochiral substrates [25]. Class III enzymes possess a conserved alanine at this position. Directed evolution performed on YqjM by Reetz and co-workers enabled control of the enantioselectivity for the bioreduction of substituted cyclopentenone and cyclohexenone substrates [131]. A recent review by Stewart and Amato on protein engineering of OYEs gives a good overview on the possibilities of stereochemical outcome [130].

\section{Conclusions}

We provide a new classification for the currently available and ready to use 63 OYEs, divided into three classes. The structural classification of OYEs displayed the conserved as well as the differing residues among the three classes.

Class I are monomeric OYEs originating from plants and bacteria. They prefer $\alpha$-methylated cyclic enones as substrates and showed highest reduction rates with NCB 2. Class II enzymes are fungal OYEs likely developed in a co-driven evolution from class I. Both classes are phylogenetically and structurally closely related resulting in similar substrate preferences, although class II members display higher conversions on certain substrates and those tested did not accept NCBs as well.

Class III OYEs are likely driven by a convergent evolution to class I/II resulting in a substantial distance on sequence level according to the dendrogram. Due to remarkable variances in conservation compared to the two foreign subclasses but great conservation within their own members, class III OYEs have a different structure, biochemical behaviour and substrate preference. They form oligomers built from homodimers and are often thermostable. They highly prefer maleimides as substrates and NCB 3 as the hydride donor, and accept the nitrile-substituted NCB 5 best of all classes.

The symbiosis of bioinformatics, biochemistry and biocatalysis enables a closer analysis of an industrially attractive biocatalyst, OYE, to determine from which class it should be chosen for a targeted product, and to allow further improvements with specially designed NCBs.

Supplementary Materials: The following are available online at www.mdpi.com/2073-4344/7/5/130/s1, Figures S1 and S2.

Acknowledgments: Caroline E. Paul gratefully acknowledges funding from the NWO Innovative programme Veni (grant number 722.015.011). Anika Scholtissek was financial supported by the Saxon Ministry of Science and Fine Arts and the European Union (EU) in the framework of the European Social Fund (ESF; project numbers $100,101,363$ and 100,236,458).

Author Contributions: A.S. generated the phylogenetic trees, sequence alignment and analysis; A.H.W. performed the modeling; and A.S., D.T., W.J.H.v.B. and C.E.P. wrote the paper.

Conflicts of Interest: The authors declare no conflict of interest. The founding sponsors had no role in the design of the study; in the collection, analyses, or interpretation of data; in the writing of the manuscript, and in the decision to publish the results.

\section{References}

1. Knowles, W.S.; Noyori, R. Pioneering perspectives on asymmetric hydrogenation. Acc. Chem. Res. 2007, 40, 1238-1239. [CrossRef] [PubMed]

2. Clayden, J.; Greeves, N.; Warren, S.G. Organic Chemistry, 2nd ed.; Oxford University Press: Oxford, UK; New York, NY, USA, 2012. 
3. Atkins, P.W.; Shriver, D.F. Shriver and Atkins' Inorganic Chemistry, 5th ed.; Oxford University Press: Oxford, UK; New York, NY, USA, 2010.

4. Yang, J.W.; Fonseca, M.T.H.; Vignola, N.; List, B. Metal-free, organocatalytic asymmetric transfer hydrogenation of $\alpha, \beta$-unsaturated aldehydes. Angew. Chem. Int. Ed. 2005, 44, 108-110. [CrossRef] [PubMed]

5. Williams, R.E.; Bruce, N.C. 'New uses for an old enzyme'-the old yellow enzyme family of flavoenzymes. Microbiology 2002, 148, 1607-1614. [CrossRef] [PubMed]

6. Chaparro-Riggers, J.F.; Rogers, T.A.; Vazquez-Figueroa, E.; Polizzi, K.M.; Bommarius, A.S. Comparison of three enoate reductases and their potential use for biotransformations. Adv. Synth. Catal. 2007, 349, 1521-1531. [CrossRef]

7. Stuermer, R.; Hauer, B.; Hall, M.; Faber, K. Asymmetric bioreduction of activated C=C bonds using enoate reductases from the old yellow enzyme family. Curr. Opin. Chem. Biol. 2007, 11, 203-213. [CrossRef] [PubMed]

8. Fryszkowska, A.; Toogood, H.; Sakuma, M.; Gardiner, J.M.; Stephens, G.M.; Scrutton, N.S. Asymmetric reduction of activated alkenes by pentaerythritol tetranitrate reductase: Specificity and control of stereochemical outcome by reaction optimisation. Adv. Synth. Catal. 2009, 351, 2976-2990. [CrossRef] [PubMed]

9. Toogood, H.S.; Gardiner, J.M.; Scrutton, N.S. Biocatalytic reductions and chemical versatility of the old yellow enzyme family of flavoprotein oxidoreductases. ChemCatChem 2010, 2, 892-914. [CrossRef]

10. Gao, X.Z.; Ren, J.; Wu, Q.Q.; Zhu, D.M. Biochemical characterization and substrate profiling of a new NADH-dependent enoate reductase from Lactobacillus casei. Enzyme Microb. Technol. 2012, 51, $26-34$. [CrossRef] [PubMed]

11. Swiderska, M.A.; Stewart, J.D. Stereoselective enone reductions by Saccharomyces carlsbergensis old yellow enzyme. J. Mol. Catal. B Enzym. 2006, 42, 52-54. [CrossRef]

12. Hall, M.; Stueckler, C.; Ehammer, H.; Pointner, E.; Oberdorfer, G.; Gruber, K.; Hauer, B.; Stuermer, R.; Kroutil, W.; Macheroux, P.; et al. Asymmetric bioreduction of $\mathrm{C}=\mathrm{C}$ bonds using enoate reductases OPR1, OPR3 and YqjM: Enzyme-based stereocontrol. Adv. Synth. Catal. 2008, 350, 411-418. [CrossRef]

13. Bertolotti, M.; Brenna, E.; Crotti, M.; Gatti, F.G.; Monti, D.; Parmeggiani, F.; Santangelo, S. Substrate scope evaluation of the enantioselective reduction of $\beta$-alkyl- $\beta$-arylnitroalkenes by old yellow enzymes $1-3$ for organic synthesis applications. ChemCatChem 2016, 8, 577-583. [CrossRef]

14. Nivinskas, H.; Sarlauskas, J.; Anusevicius, Z.; Toogood, H.S.; Scrutton, N.S.; Cenas, N. Reduction of aliphatic nitroesters and $N$-nitramines by Enterobacter cloacae PB2 pentaerythritol tetranitrate reductase. FEBS J. 2008, 275, 6192-6203. [CrossRef] [PubMed]

15. Toogood, H.S.; Fryszkowska, A.; Hare, V.; Fisher, K.; Roujeinikova, A.; Leys, D.; Gardiner, J.M.; Stephens, G.M.; Scrutton, N.S. Structure-based insight into the asymmetric bioreduction of the C=C double bond of $\alpha, \beta$-unsaturated nitroalkenes by pentaerythritol tetranitrate reductase. Adv. Synth. Catal. 2008, 350, 2789-2803. [CrossRef] [PubMed]

16. Liu, Y.J.; Pei, X.Q.; Lin, H.; Gai, P.; Liu, Y.C.; Wu, Z.L. Asymmetric bioreduction of activated alkenes by a novel isolate of Achromobacter species producing enoate reductase. Appl. Microbiol. Biotechnol. 2012, 95, 635-645. [CrossRef] [PubMed]

17. Wang, H.B.; Pei, X.Q.; Wu, Z.L. An enoate reductase Achr-OYE4 from Achromobacter sp. JA81: Characterization and application in asymmetric bioreduction of $\mathrm{C}=\mathrm{C}$ bonds. Appl. Microbiol. Biotechnol. 2014, 98, 705-715. [CrossRef] [PubMed]

18. Stueckler, C.; Hall, M.; Ehammer, H.; Pointner, E.; Kroutil, W.; Macheroux, P.; Faber, K. Stereocomplementary bioreduction of $\alpha, \beta$-unsaturated dicarboxylic acids and dimethyl esters using enoate reductases: Enzymeand substrate-based stereocontrol. Org. Lett. 2007, 9, 5409-5411. [CrossRef] [PubMed]

19. Tasnádi, G.; Winkler, C.K.; Clay, D.; Sultana, N.; Fabian, W.M.F.; Hall, M.; Ditrich, K.; Faber, K. A substrate-driven approach to determine reactivities of $\alpha, \beta$-unsaturated carboxylic esters towards asymmetric bioreduction. Chem. Eur. J. 2012, 18, 10362-10367. [CrossRef] [PubMed]

20. Tasnádi, G.; Winkler, C.K.; Clay, D.; Hall, M.; Faber, K. Reductive dehalogenation of $\beta$-haloacrylic ester derivatives mediated by ene-reductases. Catal. Sci. Technol. 2012, 2, 1548-1552. [CrossRef]

21. Fu, Y.L.; Hoelsch, K.; Weuster-Botz, D. A novel ene-reductase from Synechococcus sp. PCC 7942 for the asymmetric reduction of alkenes. Process. Biochem. 2012, 47, 1988-1997. [CrossRef] 
22. Riedel, A.; Mehnert, M.; Paul, C.E.; Westphal, A.H.; van Berkel, W.J.H.; Tischler, D. Functional characterization and stability improvement of a 'thermophilic-like' ene-reductase from Rhodococcus opacus 1CP. Front. Microbiol. 2015, 6, 1073. [CrossRef] [PubMed]

23. Scholtissek, A.; Ullrich, S.R.; Mühling, M.; Schlömann, M.; Paul, C.E.; Tischler, D. A thermophilic-like ene-reductase originating from an acidophilic iron oxidizer. Appl. Microbiol. Biotechnol. 2017, 101, $609-619$. [CrossRef] [PubMed]

24. Winkler, C.K.; Clay, D.; Turrini, N.G.; Lechner, H.; Kroutil, W.; Davies, S.; Debarge, S.; O’Neill, P.; Steflik, J.; Karmilowicz, M.; et al. Nitrile as activating group in the asymmetric bioreduction of $\beta$-cyanoacrylic acids catalyzed by ene-reductases. Adv. Synth. Catal. 2014, 356, 1878-1882. [CrossRef] [PubMed]

25. Brenna, E.; Crotti, M.; Gatti, F.G.; Monti, D.; Parmeggiani, F.; Powell, R.W.; Santangelo, S.; Stewart, J.D. Opposite enantioselectivity in the bioreduction of $(Z)-\beta$-aryl- $\beta$-cyanoacrylates mediated by the tryptophan 116 mutants of old yellow enzyme 1: Synthetic approach to $(R)$-and (S)- $\beta$-aryl- $\gamma$-lactams. Adv. Synth. Catal. 2015, 357, 1849-1860. [CrossRef]

26. Swiderska, M.A.; Stewart, J.D. Asymmetric bioreductions of $\beta$-nitro acrylates as a route to chiral $\beta^{2}$-amino acids. Org. Lett. 2006, 8, 6131-6133. [CrossRef] [PubMed]

27. Durchschein, K.; Hall, M.; Faber, K. Unusual reactions mediated by FMN-dependent ene- and nitro-reductases. Green Chem. 2013, 15, 1764-1772. [CrossRef]

28. Wohlgemuth, R. Biocatalysis-key to sustainable industrial chemistry. Curr. Opin. Biotechnol. 2010, $21,713-724$. [CrossRef] [PubMed]

29. Bougioukou, D.J.; Walton, A.Z.; Stewart, J.D. Towards preparative-scale, biocatalytic alkene reductions. Chem. Commun. 2010, 46, 8558-8560. [CrossRef] [PubMed]

30. Huisman, G.W.; Collier, S.J. On the development of new biocatalytic processes for practical pharmaceutical synthesis. Curr. Opin. Chem. Biol. 2013, 17, 284-292. [CrossRef] [PubMed]

31. Ress, T.; Hummel, W.; Hanlon, S.P.; Iding, H.; Gröger, H. The organic-synthetic potential of recombinant ene reductases: Substrate-scope evaluation and process optimization. ChemCatChem 2015, 7, 1302-1311. [CrossRef]

32. Pietruszka, J.; Scholzel, M. Ene reductase-catalysed synthesis of (R)-profen derivatives. Adv. Synth. Catal. 2012, 354, 751-756. [CrossRef]

33. Winkler, C.K.; Clay, D.; Davies, S.; O’Neill, P.; McDaid, P.; Debarge, S.; Steflik, J.; Karmilowicz, M.; Wong, J.W.; Faber, K. Chemoenzymatic asymmetric synthesis of pregabalin precursors via asymmetric bioreduction of $\beta$-cyanoacrylate esters using ene-reductases. J. Org. Chem. 2013, 78, 1525-1533. [CrossRef] [PubMed]

34. Turrini, N.G.; Hall, M.; Faber, K. Enzymatic synthesis of optically active lactones via asymmetric bioreduction using ene-reductases from the old yellow enzyme family. Adv. Synth. Catal. 2015, 357, 1861-1871. [CrossRef]

35. Collins, I. Saturated and unsaturated lactones. J. Chem. Soc. Perkin Trans. 1999, 1, 1377-1395. [CrossRef]

36. Toogood, H.S.; Scrutton, N.S. New developments in 'ene'-reductase catalysed biological hydrogenations. Curr. Opin. Chem. Biol. 2014, 19, 107-115. [CrossRef] [PubMed]

37. Breithaupt, C.; Strassner, J.; Breitinger, U.; Huber, R.; Macheroux, P.; Schaller, A.; Clausen, T. X-ray structure of 12-oxophytodienoate reductase 1 provides structural insight into substrate binding and specificity within the family of OYE. Structure 2001, 9, 419-429. [CrossRef]

38. Kohli, R.M.; Massey, V. The oxidative half-reaction of old yellow enzyme-The role of tyrosine 196. J. Biol. Chem. 1998, 273, 32763-32770. [CrossRef] [PubMed]

39. Lonsdale, R.; Reetz, M.T. Reduction of $\alpha, \beta$-unsaturated ketones by old yellow enzymes: Mechanistic insights from quantum mechanics/molecular mechanics calculations. J. Am. Chem. Soc. 2015, 137, 14733-14742. [CrossRef] [PubMed]

40. Karplus, P.A.; Fox, K.M.; Massey, V. Flavoprotein structure and mechanism. 8. Structure-function relations for old yellow enzyme. FASEB J. 1995, 9, 1518-1526. [PubMed]

41. Brown, B.J.; Hyun, J.W.; Duvvuri, S.; Karplus, P.A.; Massey, V. The role of glutamine 114 in old yellow enzyme. J. Biol. Chem. 2002, 277, 2138-2145. [CrossRef] [PubMed]

42. Hall, M.; Stueckler, C.; Hauer, B.; Stuermer, R.; Friedrich, T.; Breuer, M.; Kroutil, W.; Faber, K. Asymmetric bioreduction of activated $\mathrm{C}=\mathrm{C}$ bonds using Zymomonas mobilis NCR enoate reductase and old yellow enzymes OYE 1-3 from yeasts. Eur. J. Org. Chem. 2008, 1511-1516. [CrossRef] 
43. Hall, M.; Stueckler, C.; Kroutil, W.; Macheroux, P.; Faber, K. Asymmetric bioreduction of activated alkenes using cloned 12-oxophytodienoate reductase isoenzymes OPR-1 and OPR-3 from Lycopersicon esculentum (tomato): A striking change of stereoselectivity. Angew. Chem. Int. Ed. 2007, 46, 3934-3937. [CrossRef] [PubMed]

44. Mueller, N.J.; Stueckler, C.; Hauer, B.; Baudendistel, N.; Housden, H.; Bruce, N.C.; Faber, K. The substrate spectra of pentaerythritol tetranitrate reductase, morphinone reductase, $N$-ethylmaleimide reductase and estrogen-binding protein in the asymmetric bioreduction of activated alkenes. Adv. Synth. Catal. 2010, 352, 387-394. [CrossRef]

45. Tauber, K.; Hall, M.; Kroutil, W.; Fabian, W.M.F.; Faber, K.; Glueck, S.M. A highly efficient ADH-coupled NADH-recycling system for the asymmetric bioreduction of carbon-carbon double bonds using enoate reductases. Biotechnol. Bioeng. 2011, 108, 1462-1467. [CrossRef] [PubMed]

46. Toogood, H.S.; Knaus, T.; Scrutton, N.S. Alternative hydride sources for ene-reductases: Current trends. ChemCatChem 2014, 6, 951-954. [CrossRef]

47. Peers, M.K.; Toogood, H.S.; Heyes, D.J.; Mansell, D.; Coe, B.J.; Scrutton, N.S. Light-driven biocatalytic reduction of $\alpha, \beta$-unsaturated compounds by ene reductases employing transition metal complexes as photosensitizers. Catal. Sci. Technol. 2016, 6, 169-177. [CrossRef] [PubMed]

48. Winkler, C.K.; Clay, D.; Entner, M.; Plank, M.; Faber, K. NAD(P)H-independent asymmetric C=C bond reduction catalyzed by ene reductases by using artificial co-substrates as the hydrogen donor. Chem. Eur. J. 2014, 20, 1403-1409. [CrossRef] [PubMed]

49. Winkler, C.K.; Clay, D.; van Heerden, E.; Faber, K. Overcoming co-product inhibition in the nicotinamide independent asymmetric bioreduction of activated $\mathrm{C}=\mathrm{C}$-bonds using flavin-dependent ene-reductases. Biotechnol. Bioeng. 2013, 110, 3085-3092. [CrossRef] [PubMed]

50. Durchschein, K.; Wallner, S.; Macheroux, P.; Schwab, W.; Winkler, T.; Kreis, W.; Faber, K. Nicotinamide-dependent ene reductases as alternative biocatalysts for the reduction of activated alkenes. Eur. J. Org. Chem. 2012, 4963-4968. [CrossRef]

51. Stueckler, C.; Reiter, T.C.; Baudendistel, N.; Faber, K. Nicotinamide-independent asymmetric bioreduction of $\mathrm{C}=\mathrm{C}$-bonds via disproportionation of enones catalyzed by enoate reductases. Tetrahedron 2010, 66, 663-667. [CrossRef] [PubMed]

52. Paul, C.E.; Gargiulo, S.; Opperman, D.J.; Lavandera, I.; Gotor-Fernández, V.; Gotor, V.; Taglieber, A.; Arends, I.W.C.E.; Hollmann, F. Mimicking nature: Synthetic nicotinamide cofactors for $\mathrm{C}=\mathrm{C}$ bioreduction using enoate reductases. Org. Lett. 2013, 15, 180-183. [CrossRef] [PubMed]

53. Paul, C.E.; Arends, I.W.C.E.; Hollmann, F. Is simpler better? Synthetic nicotinamide cofactor analogues for redox chemistry. ACS Catal. 2014, 4, 788-797. [CrossRef]

54. Hollmann, F.; Paul, C.E. Synthetische nikotinamide in der biokatalyse. BIOspektrum 2015, 21, 376-378. [CrossRef]

55. Paul, C.E.; Hollmann, F. A survey of synthetic nicotinamide cofactors in enzymatic processes. Appl. Microbiol. Biotechnol. 2016, 100, 4773-4778. [CrossRef] [PubMed]

56. Okamoto, Y.; Köhler, V.; Paul, C.E.; Hollmann, F.; Ward, T.R. Efficient in situ regeneration of NADH mimics by an artificial metalloenzyme. ACS Catal. 2016, 6, 3553-3557. [CrossRef]

57. Geddes, A.; Paul, C.E.; Hay, S.; Hollmann, F.; Scrutton, N.S. Donor-acceptor distance sampling enhances the performance of "better than Nature" nicotinamide coenzyme biomimetics. J. Am. Chem. Soc. 2016, 138, 11089-11092. [CrossRef] [PubMed]

58. Löw, S.A.; Löw, I.M.; Weissenborn, M.J.; Hauer, B. Enhanced ene-reductase activity through alteration of artificial nicotinamide cofactor substituents. ChemCatChem 2016, 8, 911-915. [CrossRef]

59. Knaus, T.; Paul, C.E.; Levy, C.W.; de Vries, S.; Mutti, F.G.; Hollmann, F.; Scrutton, N.S. Better than Nature: Nicotinamide biomimetics that outperform natural coenzymes. J. Am. Chem. Soc. 2016, 138, 1033-1039. [CrossRef] [PubMed]

60. Winkler, C.K.; Tasnádi, G.; Clay, D.; Hall, M.; Faber, K. Asymmetric bioreduction of activated alkenes to industrially relevant optically active compounds. J. Biotechnol. 2012, 162, 381-389. [CrossRef] [PubMed]

61. Saito, K.; Thiele, D.J.; Davio, M.; Lockridge, O.; Massey, V. The cloning and expression of a gene encoding old yellow enzyme from Saccharomyces carlsbergensis. J. Biol. Chem. 1991, 266, 20720-20724. [PubMed] 
62. Kataoka, M.; Kotaka, A.; Hasegawa, A.; Wada, M.; Yoshizumi, A.; Nakamori, S.; Shimizu, S. Old yellow enzyme from Candida macedoniensis catalyzes the stereospecific reduction of the $\mathrm{C}=\mathrm{C}$ bond of ketoisophorone. Biosci. Biotechnol. Biochem. 2002, 66, 2651-2657. [CrossRef] [PubMed]

63. Nizam, S.; Verma, S.; Borah, N.N.; Gazara, R.K.; Verma, P.K. Comprehensive genome-wide analysis reveals different classes of enigmatic old yellow enzyme in fungi. Sci. Rep. 2014, 4, 4013. [CrossRef] [PubMed]

64. Nizam, S.; Gazara, R.K.; Verma, S.; Singh, K.; Verma, P.K. Comparative structural modeling of six old yellow enzymes (OYEs) from the necrotrophic fungus Ascochyta rabiei: Insight into novel OYE classes with differences in cofactor binding, organization of active site residues and stereopreferences. PLOS ONE 2014, 9, e95989. [CrossRef] [PubMed]

65. Schaller, F.; Weiler, E.W. Molecular cloning and characterization of 12-oxophytodienoate reductase, an enzyme of the octadecanoid signaling pathway from Arabidopsis thaliana-Structural and functional relationship to yeast old yellow enzyme. J. Biol. Chem. 1997, 272, 28066-28072. [CrossRef] [PubMed]

66. Müssig, C.; Biesgen, C.; Lisso, J.; Uwer, U.; Weiler, E.W.; Altmann, T. A novel stress-inducible 12-oxophytodienoate reductase from Arabidopsis thaliana provides a potential link between Brassinosteroid-action and Jasmonic-acid synthesis. J. Plant Physiol. 2000, 157, 143-152. [CrossRef]

67. Strassner, J.; Schaller, F.; Frick, U.B.; Howe, G.A.; Weiler, E.W.; Amrhein, N.; Macheroux, P.; Schaller, A. Characterization and CDNA-microarray expression analysis of 12-oxophytodienoate reductases reveals differential roles for octadecanoid biosynthesis in the local versus the systemic wound response. Plant $J$. 2002, 32, 585-601. [CrossRef] [PubMed]

68. Strassner, J.; Furholz, A.; Macheroux, P.; Amrhein, N.; Schaller, A. A homolog of old yellow enzyme in tomato-Spectral properties and substrate specificity of the recombinant protein. J. Biol. Chem. 1999, 274, 35067-35073. [CrossRef] [PubMed]

69. French, C.E.; Nicklin, S.; Bruce, N.C. Sequence and properties of pentaerythritol tetranitrate reductase from Enterobacter cloacae PB2. J. Bacteriol. 1996, 178, 6623-6627. [CrossRef] [PubMed]

70. Blehert, D.S.; Knoke, K.L.; Fox, B.G.; Chambliss, G.H. Regioselectivity of nitroglycerin denitration by flavoprotein nitroester reductases purified from two Pseudomonas species. J. Bacteriol. 1997, 179, 6912-6920. [CrossRef] [PubMed]

71. Husserl, J.; Hughes, J.B.; Spain, J.C. Key enzymes enabling the growth of Arthrobacter sp. strain JBH1 with nitroglycerin as the sole source of carbon and nitrogen. Appl. Environ. Microbiol. 2012, 78, 3649-3655. [CrossRef] [PubMed]

72. Khairy, H.; Wübbeler, J.H.; Steinbüchel, A. The NADH: Flavin oxidoreductase Nox from Rhodococcus erythropolis MI2 is the key enzyme of 4,4'-dithiodibutyric acid degradation. Lett. Appl. Microbiol. 2016, 63, 434-441. [CrossRef] [PubMed]

73. Pei, X.Q.; Xu, M.Y.; Wu, Z.L. Two “classical” old yellow enzymes from Chryseobacterium sp. CA49: Broad substrate specificity of Chr-OYE1 and limited activity of Chr-OYE2. J. Mol. Catal. B Enzym. 2016, 123, 91-99. [CrossRef]

74. Xu, M.Y.; Pei, X.Q.; Wu, Z.L. Identification and characterization of a novel "thermophilic-like" old yellow enzyme from the genome of Chryseobacterium sp. CA49. J. Mol. Catal. B Enzym. 2014, 108, 64-71. [CrossRef]

75. Kitzing, K.; Fitzpatrick, T.B.; Wilken, C.; Sawa, J.; Bourenkov, G.P.; Macheroux, P.; Clausen, T. The $1.3 \AA$ crystal structure of the flavoprotein YqjM reveals a novel class of old yellow enzymes. J. Biol. Chem. 2005, 280, 27904-27913. [CrossRef] [PubMed]

76. Schittmayer, M.; Glieder, A.; Uhl, M.K.; Winkler, A.; Zach, S.; Schrittwieser, J.H.; Kroutil, W.; Macheroux, P.; Gruber, K.; Kambourakis, S.; et al. Old yellow enzyme-catalyzed dehydrogenation of saturated ketones. Adv. Synth. Catal. 2011, 353, 268-274. [CrossRef]

77. Adalbjörnsson, B.V.; Toogood, H.S.; Fryszkowska, A.; Pudney, C.R.; Jowitt, T.A.; Leys, D.; Scrutton, N.S. Biocatalysis with thermostable enzymes: Structure and properties of a thermophilic 'ene'-reductase related to old yellow enzyme. ChemBioChem 2010, 11, 197-207. [CrossRef] [PubMed]

78. Opperman, D.J.; Sewell, B.T.; Litthauer, D.; Isupov, M.N.; Littlechild, J.A.; van Heerden, E. Crystal structure of a thermostable old yellow enzyme from Thermus scotoductus SA-01. Biochem. Biophys. Res. Commun. 2010, 393, 426-431. [CrossRef] [PubMed]

79. Opperman, D.J.; Piater, L.A.; van Heerden, E. A novel chromate reductase from Thermus scotoductus SA-01 related to old yellow enzyme. J. Bacteriol. 2008, 190, 3076-3082. [CrossRef] [PubMed] 
80. Litthauer, S.; Gargiulo, S.; van Heerden, E.; Hollmann, F.; Opperman, D.J. Heterologous expression and characterization of the ene-reductases from Deinococcus radiodurans and Ralstonia metallidurans. J. Mol. Catal. B Enzym. 2014, 99, 89-95. [CrossRef]

81. Fu, Y.L.; Castiglione, K.; Weuster-Botz, D. Comparative characterization of novel ene-reductases from cyanobacteria. Biotechnol. Bioeng. 2013, 110, 1293-1301. [CrossRef] [PubMed]

82. Warburg, O.; Christian, W. Yellow enzyme and its effects. Biochem. Z. 1933, 266, 377-411.

83. Fox, K.M.; Karplus, P.A. Old yellow enzyme at $2 \AA$ resolution: Overall structure, ligand-binding, and comparison with related flavoproteins. Structure 1994, 2, 1089-1105. [CrossRef]

84. Müller, A.; Hauer, B.; Rosche, B. Asymmetric alkene reduction by yeast old yellow enzymes and by a novel Zymomonas mobilis reductase. Biotechnol. Bioeng. 2007, 98, 22-29. [CrossRef] [PubMed]

85. French, C.E.; Bruce, N.C. Purification and characterization of morphinone reductase from Pseudomonas putida M10. Biochem. J. 1994, 301, 97-103. [CrossRef] [PubMed]

86. Haas, E. Isolation of a new yellow enzyme. Biochem. Z. 1938, 298, 378-390.

87. Stott, K.; Saito, K.; Thiele, D.J.; Massey, V. Old yellow enzyme-the discovery of multiple isozymes and a family of related proteins. J. Biol. Chem. 1993, 268, 6097-6106. [PubMed]

88. Niino, Y.S.; Chakraborty, S.; Brown, B.J.; Massey, V. A new old yellow enzyme of Saccharomyces cerevisiae. J. Biol. Chem. 1995, 270, 1983-1991. [PubMed]

89. Madani, N.D.; Malloy, P.J.; Rodriguezpombo, P.; Krishnan, A.V.; Feldman, D. Candida albicans estrogen-binding protein gene encodes an oxidoreductase that is inhibited by estradiol. Proc. Natl. Acad. Sci. USA 1994, 91, 922-926. [CrossRef] [PubMed]

90. Komduur, J.A.; Leao, A.N.; Monastyrska, I.; Veenhuis, M.; Kiel, J.A.K.W. Old yellow enzyme confers resistance of Hansenula polymorpha towards allyl alcohol. Curr. Genet. 2002, 41, 401-406. [CrossRef] [PubMed]

91. Kataoka, M.; Kotaka, A.; Thiwthong, R.; Wada, M.; Nakamori, S.; Shimizu, S. Cloning and overexpression of the old yellow enzyme gene of Candida macedoniensis, and its application to the production of a chiral compound. J. Biotechnol. 2004, 114, 1-9. [CrossRef] [PubMed]

92. Miranda, M.; Ramirez, J.; Guevara, S.; Ongaylarios, L.; Pena, A.; Coria, R. Nucleotide-sequence and chromosomal localization of the gene encoding the old yellow enzyme from Kluyveromyces lactis. Yeast 1995, 11, 459-465. [CrossRef] [PubMed]

93. Padhi, S.K.; Bougioukou, D.J.; Stewart, J.D. Site-saturation mutagenesis of tryptophan 116 of Saccharomyces pastorianus old yellow enzyme uncovers stereocomplementary variants. J. Am. Chem. Soc. 2009, 131, 3271-3280. [CrossRef] [PubMed]

94. Patterson-Orazem, A.; Sullivan, B.; Stewart, J.D. Pichia stipitis OYE 2.6 variants with improved catalytic efficiencies from site-saturation mutagenesis libraries. Bioorg. Med. Chem. 2014, 22, 5628-5632. [CrossRef] [PubMed]

95. Ni, Y.; Yu, H.L.; Lin, G.Q.; Xu, J.H. An ene reductase from Clavispora lusitaniae for asymmetric reduction of activated alkenes. Enzyme Microb. Technol. 2014, 56, 40-45. [CrossRef] [PubMed]

96. Zhang, B.Q.; Zheng, L.D.; Lin, J.P.; Wei, D.Z. Characterization of an ene-reductase from Meyerozyma guilliermondii for asymmetric bioreduction of $\alpha, \beta$-unsaturated compounds. Biotechnol. Lett. 2016, 38, 1527-1534. [CrossRef] [PubMed]

97. Biesgen, C.; Weiler, E.W. Structure and regulation of OPR1 and OPR2, two closely related genes encoding 12-oxophytodienoic acid-10,11-reductases from Arabidopsis thaliana. Planta 1999, 208, 155-165. [CrossRef] [PubMed]

98. Snape, J.R.; Walkley, N.A.; Morby, A.P.; Nicklin, S.; White, G.F. Purification, properties, and sequence of glycerol trinitrate reductase from Agrobacterium radiobacter. J. Bacteriol. 1997, 179, 7796-7802. [CrossRef] [PubMed]

99. Richter, N.; Gröger, H.; Hummel, W. Asymmetric reduction of activated alkenes using an enoate reductase from Gluconobacter oxydans. Appl. Microbiol. Biotechnol. 2011, 89, 79-89. [CrossRef] [PubMed]

100. Miura, K.; Tomioka, Y.; Suzuki, H.; Yonezawa, M.; Hishinuma, T.; Mizugaki, M. Molecular cloning of the nemA gene encoding N-ethylmaleimide reductase from Escherichia coli. Biol. Pharm. Bull. 1997, 20, 110-112. [CrossRef] [PubMed]

101. Peters, C.; Kolzsch, R.; Kadow, M.; Skalden, L.; Rudroff, F.; Mihovilovic, M.D.; Bornscheuer, U.T. Identification, characterization, and application of three enoate reductases from Pseudomonas putida in in vitro enzyme cascade reactions. Chem CatChem 2014, 6, 1021-1027. [CrossRef] 
102. Blehert, D.S.; Fox, B.G.; Chambliss, G.H. Cloning and sequence analysis of two Pseudomonas flavoprotein xenobiotic reductases. J. Bacteriol. 1999, 181, 6254-6263. [PubMed]

103. Brigé, A.; van den Hemel, D.; Carpentier, W.; De Smet, L.; Van Beeumen, J.J. Comparative characterization and expression analysis of the four old yellow enzyme homologues from Shewanella oneidensis indicate differences in physiological function. Biochem. J. 2006, 394, 335-344. [CrossRef] [PubMed]

104. Sheng, X.Q.; Yan, M.; Xu, L.; Wei, M. Identification and characterization of a novel old yellow enzyme from Bacillus subtilis str.168. J. Mol. Catal. B Enzym. 2016, 130, 18-24. [CrossRef]

105. Tsuji, N.; Honda, K.; Wada, M.; Okano, K.; Ohtake, H. Isolation and characterization of a thermotolerant ene reductase from Geobacillus sp. 30 and its heterologous expression in Rhodococcus opacus. Appl. Microbiol. Biotechnol. 2014, 98, 5925-5935. [CrossRef] [PubMed]

106. Fitzpatrick, T.B.; Amrhein, N.; Macheroux, P. Characterization of YqjM, an old yellow enzyme homolog from Bacillus subtilis involved in the oxidative stress response. J. Biol. Chem. 2003, 278, 19891-19897. [CrossRef] [PubMed]

107. Brooks, D.J.; Fresco, J.R.; Lesk, A.M.; Singh, M. Evolution of amino acid frequencies in proteins over deep time: Inferred order of introduction of amino acids into the genetic code. Mol. Biol. Evol. 2002, 19, 1645-1655. [CrossRef] [PubMed]

108. Longo, L.M.; Blaber, M. Protein design at the interface of the pre-biotic and biotic worlds. Arch. Biochem. Biophys. 2012, 526, 16-21. [CrossRef] [PubMed]

109. Barna, T.; Messiha, H.L.; Petosa, C.; Bruce, N.C.; Scrutton, N.S.; Moody, P.C.E. Crystal structure of bacterial morphinone reductase and properties of the C191A mutant enzyme. J. Biol. Chem. 2002, 277, 30976-30983. [CrossRef] [PubMed]

110. Wierenga, R.K. The TIM-barrel fold: A versatile framework for efficient enzymes. FEBS Lett. 2001, 492, 193-198. [CrossRef]

111. Barna, T.M.; Khan, H.; Bruce, N.C.; Barsukov, I.; Scrutton, N.S.; Moody, P.C.E. Crystal structure of pentaerythritol tetranitrate reductase: "Flipped" binding geometries for steroid substrates in different redox states of the enzyme. J. Mol. Biol. 2001, 310, 433-447. [CrossRef] [PubMed]

112. Spiegelhauer, O.; Werther, T.; Mende, S.; Knauer, S.H.; Dobbek, H. Determinants of substrate binding and protonation in the flavoenzyme Xenobiotic reductase A. J. Mol. Biol. 2010, 403, 286-298. [CrossRef] [PubMed]

113. Xu, D.; Kohli, R.M.; Massey, V. The role of threonine 37 in flavin reactivity of the old yellow enzyme. Proc. Natl. Acad. Sci. USA 1999, 96, 3556-3561. [CrossRef] [PubMed]

114. Messiha, H.L.; Bruce, N.C.; Sattelle, B.M.; Sutcliffe, M.J.; Munro, A.W.; Scrutton, N.S. Role of active site residues and solvent in proton transfer and the modulation of flavin reduction potential in bacterial morphinone reductase. J. Biol. Chem. 2005, 280, 27103-27110. [CrossRef] [PubMed]

115. Spiegelhauer, O.; Dickert, F.; Mende, S.; Niks, D.; Hille, R.; Ullmann, M.; Dobbek, H. Kinetic characterization of Xenobiotic reductase A from Pseudomonas putida 86. Biochemistry 2009, 48, 11412-11420. [CrossRef] [PubMed]

116. Pudney, C.R.; Hay, S.; Pang, J.Y.; Costello, C.; Leys, D.; Sutcliffe, M.J.; Scrutton, N.S. Mutagenesis of morphinone reductase induces multiple reactive configurations and identifies potential ambiguity in kinetic analysis of enzyme tunneling mechanisms. J. Am. Chem. Soc. 2007, 129, 13949-13956. [CrossRef] [PubMed]

117. Williams, R.E.; Rathbone, D.A.; Scrutton, N.S.; Bruce, N.C. Biotransformation of explosives by the old yellow enzyme family of flavoproteins. Appl. Environ. Microbiol. 2004, 70, 3566-3574. [CrossRef] [PubMed]

118. Reich, S.; Nestl, B.M.; Hauer, B. Loop-grafted old yellow enzymes in the bienzymatic cascade reduction of allylic alcohols. ChemBioChem 2016, 17, 561-565. [CrossRef] [PubMed]

119. Nestl, B.M.; Hauer, B. Engineering of flexible loops in enzymes. ACS Catal. 2014, 4, 3201-3211. [CrossRef]

120. Reich, S.; Kress, N.; Nestl, B.M.; Hauer, B. Variations in the stability of NCR ene reductase by rational enzyme loop modulation. J. Struct. Biol. 2014, 185, 228-233. [CrossRef] [PubMed]

121. Basran, J.; Harris, R.J.; Sutcliffe, M.J.; Scrutton, N.S. H-tunneling in the multiple H-transfers of the catalytic cycle of morphinone reductase and in the reductive half-reaction of the homologous pentaerythritol tetranitrate reductase. J. Biol. Chem. 2003, 278, 43973-43982. [CrossRef] [PubMed]

122. Pudney, C.R.; Hay, S.; Sutcliffe, M.J.; Scrutton, N.S. $\alpha$-Secondary isotope effects as probes of "tunneling-ready" configurations in enzymatic H-tunneling: Insight from environmentally coupled tunneling models. J. Am. Chem. Soc. 2006, 128, 14053-14058. [CrossRef] [PubMed] 
123. Pudney, C.R.; Hay, S.; Levy, C.; Pang, J.Y.; Sutcliffe, M.J.; Leys, D.; Scrutton, N.S. Evidence to support the hypothesis that promoting vibrations enhance the rate of an enzyme catalyzed H-tunneling reaction. J. Am. Chem. Soc. 2009, 131, 17072-17073. [CrossRef] [PubMed]

124. Brenna, E.; Gatti, F.G.; Monti, D.; Parmeggiani, F.; Serra, S. Stereochemical outcome of the biocatalysed reduction of activated tetrasubstituted olefins by old yellow enzymes 1-3. Adv. Synth. Catal. 2012, 354, 105-112. [CrossRef]

125. Oberdorfer, G.; Steinkellner, G.; Stueckler, C.; Faber, K.; Gruber, K. Stereopreferences of old yellow enzymes: Structure correlations and sequence patterns in enoate reductases. ChemCatChem 2011, 3, 1562-1566. [CrossRef]

126. Classen, T.; Pietruszka, J.; Schuback, S.M. Revisiting the enantioselective sequence patterns in enoate reductases. ChemCatChem 2013, 5, 711-713. [CrossRef]

127. Pompeu, Y.A.; Sullivan, B.; Stewart, J.D. X-ray crystallography reveals how subtle changes control the orientation of substrate binding in an alkene reductase. ACS Catal. 2013, 3, 2376-2390. [CrossRef]

128. Walton, A.Z.; Sullivan, B.; Patterson-Orazem, A.C.; Stewart, J.D. Residues controlling facial selectivity in an alkene reductase and semirational alterations to create stereocomplementary variants. ACS Catal. 2014, 4, 2307-2318. [CrossRef] [PubMed]

129. Walton, A.Z.; Conerly, W.C.; Pompeu, Y.; Sullivan, B.; Stewart, J.D. Biocatalytic reductions of Baylis-Hillman adducts. ACS Catal. 2011, 1, 989-993. [CrossRef]

130. Amato, E.D.; Stewart, J.D. Applications of protein engineering to members of the old yellow enzyme family. Biotechnol. Adv. 2015, 33, 624-631. [CrossRef] [PubMed]

131. Bougioukou, D.J.; Kille, S.; Taglieber, A.; Reetz, M.T. Directed evolution of an enantioselective enoate-reductase: Testing the utility of iterative saturation mutagenesis. Adv. Synth. Catal. 2009, 351, 3287-3305. [CrossRef]

(c) 2017 by the authors. Licensee MDPI, Basel, Switzerland. This article is an open access article distributed under the terms and conditions of the Creative Commons Attribution (CC BY) license (http:/ / creativecommons.org/licenses/by/4.0/). 